\title{
Antecedents of Employees' Entrepreneurial Orientation: The role of Organizational Culture and the Enabling Environment
}

\author{
Kulsoom Arif Hashmi \\ Karachi University Business School, University of Karachi \\ Main University Rd, Karachi, Pakistan \\ E-mail: kulsoomarif28@gmail.com \\ Dr. Danish Ahmed Siddiqui \\ Karachi University Business School, University of Karachi \\ Main University Rd, Karachi, Pakistan \\ E-mail: daanish79@ hotmail.com
}

Received: June 7, 2020 Accepted: July 6, 2020 Published: July 22, 2020

doi:10.5296/ber.v10i3.17398ＵRL: https://doi.org/10.5296/ber.v10i3.17398

\begin{abstract}
There is an abundant literature on Entrepreneurship within organization, but the evidence on how it is caused, is still dispersed. Moreover, it still lacks a proper theoretical framework. Brettel et al., (2015) used Competing Values Model in explaining the effect of organisational culture on Entrepreneurial Orientation. We modified this model, including enabling environment factors, as well as more enriched dimensions of Entrepreneurial Orientation. Hence we hypothesized that organizational culture (Clan, Hierarchical, Developmental, Rational, and Open Culture), and enabling environment (Flexibility/ support, Open Communication, External Orientation, and Team Work) affect Employees' Entrepreneurial Orientation measured by new product innovation, new organizational practice, proactivity, and risk-taking. We applied this model by conducted a survey using likert scale type questionnaire. The data was collected from 325 employees working in various organizations in Karachi. Data was analyzed utilizing corroborative factor analysis and organized equation modeling. The results disclosed that new product innovation was positively influenced by Rational Culture, Open Culture, Flexibility, and External Orientation. And negatively affected
\end{abstract}


by Clan Culture. Similarly, risk taking ability is positively influenced by Developmental Culture, External Orientation, and Team Work. Proactivity is positively affected by Rational Culture, and External Orientation. Unlike Innovation, which was negatively affected by Clan culture, New Organizational Practice got positively affected along with Open Communication.

Keywords: Clan Culture, Hierarchical Culture, Developmental Culture, Rational Culture, Open Culture, Flexibility, Open Communication, External Orientation, Team Work, New product innovation, New organizational practice, Proactivity, Risk-taking

\section{Introduction}

\subsection{Background}

In today's business world, innovation is a major pillar of success for all organizations. Rapidly changing technologies, shortening the product life cycle, and accelerating product development can accelerate the pace of innovation and change the nature of economic development. Innovation is currently at the heart of organizational strategies to achieve and maintain competitiveness in the market. This becomes more complex as customer needs and technology change rapidly. Innovation alludes to the introduction of an organization in a new product or new product quality, production method, market, source, and / or industry. The goal is also to improve existing concepts and ideas by creating a commercially viable product using a stepwise process. Innovation tends to be very dynamic, it is considered an essential for all businesses including Multinational companies, Large Businesses, Small businesses or start-ups. The most satisfying innovation is the ability to turn an idea into a successful concept. To do this, you must follow a long and complex process. To succeed, you need to understand the process and get the support you need. This distinguishes between successful and unsuccessful innovation processes.

Product innovation is defined as; Consumption of new tools or components in the development of new products, changes to established product designs, or the manufacture of established products. Many examples of product innovation include new product introductions, quality improvements, and overall performance improvements. Product innovation, cost reduction innovation, and process innovation are three types of innovation aimed at developing the company's production methods. An atmosphere that provides the flexibility to react to transformation and provides psychosomatic security, processes, and tools to leverage the creative thinking required for innovation: a new value for creating, developing, implementing, and leveraging knowledge Generate Or an improved product, service, or process. This environment is the product of two things: the organization's members-management style, its value, behavior, attitude, communication style, and shared business practices-and infrastructure (policies, processes, etc.). And system).

Innovation is a key indicator of an organization's ability to sustain success. And in today's uncertain and complex global business environment, the ability to remain successful through a culture of innovation is becoming increasingly important. The "innovation culture" provides a competitive advantage (Shahzad, 2017). 


\section{$\triangle 1$ Macrothink}

Business and Economic Research

ISSN 2162-4860

2020, Vol. 10, No. 3

The culture of the organization is visible to employees and customers. Stories told about the organization by employees and customers give insight into the culture of the organization. If you are affecting an individual, you are affecting the team, which is affecting the organization. Before you can affect the whole thing, you need to affect the part. The reverse is also true. The vision, strategy, and direction defined at the organizational level influence teams and individuals. Culture is born from the top. The CEO and management team are primarily responsible for the culture of the organization. Their leadership style, values, behaviors, and working methods set the tone of the organization's culture. Therefore, if an organization wants a culture of innovation, management must take the lead in defining its intent, communicating it throughout the company, and demonstrating its commitment through innovation. Through his own actions and involvement in the process of achieving innovation.

Organizational practices that provide enabling environment are located just outside the core culture. They are not elements of basic culture. It is rather action that translates ideals into actions. In short, they make use of culture.

Mergers and acquisitions are responsible for cultural issues. Even a well-functioning organizational culture can develop into a malfunctioning culture after the merger. Research shows that two of the three mergers fail due to cultural issues. By mixing and redefining cultures and reconciling those differences, we are building a common platform for the future. In recent years, the rapid pace of mergers and acquisitions has changed the way companies merge. Mergers have focused on cultural fusion and achieving specific business goals. Some experts believe that a strong corporate culture will naturally develop if the right business plans and programs are implemented at the time of the merger.

\subsection{Problem Statement}

Entrepreneurial orientation is an important theory. Executives craft strategies with the hope or idea of achieving something innovative and utilizing chances that other firms cannot utilize. Entrepreneurial orientation is basically the practices, processes, styles of decision making that operate entrepreneurially. Entrepreneurial orientation of an organization can be understand with the help of competitive aggressiveness, pro-activeness, new organizational practices, autonomy, innovativeness and risk taking. Entrepreneurial orientation was developed in order to adapt rapid changes in the modern global environment for the business survival. Entrepreneurial orientation also affects the growth of the firm.

Entrepreneurial orientation face a lot of challenges like lack of training and educational facilities, insufficiency of capital (in contrast to western nations, due to increase in prices it has become difficult to sustain people's standard of living), socio cultural elements also contribute towards slow growth of entrepreneurship, opposition of changes and innovation, insufficient facilities of incentives and government, heavy corruption and taxation, lack of human and physical resources, deficiency of technical structure like professional managers, trained and specialist employees are required, risk regarding loss of invested money and lack of interest towards work etc. 


\subsection{Gap Analysis}

Shahzad et al., (2017) investigated the impact of organizational culture on innovation performance. The outcomes indicated that organizational climate, external orientation, teamwork, employees' empowerment and support to change/ flexibility significantly affects innovation performance.

Laforet, (2016) also examined the connection between organizational culture and organizational innovation. The results indicate that flexible, open culture, external oriented and long term orientation positively effects organizational innovation and open communication negatively influence organizational innovation. However, detailed explanation of cultural factor were not discussed, neither proactiveness nor risk taken were focused which could be crucial for innovation.

Cherchem, (2017) investigate the connection between organizational culture and entrepreneurial orientation. The outcomes showed that clan culture highly encourage entrepreneurship orientation (when single generation was involved). Hierarchical culture also highly encourages entrepreneurship orientation (when multiple generations were involved). Similarly, Engelen et al., (2014) studied the linkage between organizational culture and entrepreneurship orientation. The outcomes revealed that adhocracy culture (positively affects) foster organization's entrepreneurship orientation level. Whereas clan culture, market cultures and hierarchical culture negatively affects entrepreneurship orientation. However, they both lacked innovation component.

Brettel et al., (2014) examined the influence of organizational culture on innovativeness, proactiveness, and risk-taking. The results of the study showed that group, developmental and rational culture positively influences innovativeness, risk-taking and proactiveness. While hierarchical culture negatively affects innovativeness, risk-taking and proactiveness. However, they fall short in explaining enabling environment factors, as well as different dimensions of Entrepreneurial Orientation. There is an abundant literature on Entrepreneurship within organization, but the evidence on how it is caused, is still dispersed. Moreover, studies either focused on innovation component or entrepreneurship. These two factors were not studies before in a combined framework. Moreover, despite a rational figure of papers on contacts among organizational culture and innovation, as per revealed earlier, tries to combine the undefended innovation model and organization philosophy have been rare (Rass et al., 2013), (Inauen, Schenker-Wicki, 2011), (Laursen, Salter, 2006) \& (Katila, Ahuja, 2002) and thus worth undertaking. We modified Brettelet. al. (2015)'s Competing Values Model to include enabling environment factors, as well as more enriched dimensions of Entrepreneurial Orientation. No such study was conducted on Pakistan combining diverse factors like teamwork, external orientation, developmental culture, rational culture, clan culture, open culture, open communication, flexibility/ support to change, hierarchical culture (altogether) and entrepreneurial orientation remained distinguished by innovativeness, risk-taking, new organizational practice and proactiveness, in a single structural model. 


\subsection{Objectives of the Study}

This study stays a quantitative research to identify the effect of independent variable i.e. organizational culture on the dependent variables i.e. new product innovation, new organizational practice, proactivity and risk-taking. The sub-variables of organizational culture are; clan culture, hieratical culture, developmental culture, rational culture, open culture, flexibility/ support to change, open communication, external orientation and teamwork. The reason of this study is to identify the effect of organizational culture through different factors new product innovation, new organizational practice, proactivity and risk-taking.

The general objective of this investigation was that what elements affect entrepreneurial orientation and what measures should be taken to overcome these problems. The specific problem of this research was to find out the influence of organizational culture on entrepreneurial orientation.

The objective of this study includes the outcome of organizational culture on new product innovation, new organizational practice, proactivity and risk-taking. It is based on the exceeding research problems, the research objectives are as follows:

1. To determine the effect of organizational culture on new product innovation.

2. To determine the effect of organizational culture on new organizational practice.

3. To determine the effect of organizational culture on proactivity.

4. To determine the effect of organizational culture on risk-taking.

\subsection{Research Question}

The research questions for the study are:

- What is the impact of clan culture on new product innovation?

- What is the impact of clan culture on new organizational practice?

- What is the impact of clan culture on proactivity?

- What is the impact of clan culture on risk-taking?

- What is the impact of hierarchical culture on new product innovation?

- What is the impact of hierarchical culture on new organizational practice?

- What is the impact of hierarchical culture on proactivity?

- What is the impact of hierarchical culture on risk-taking?

- What is the impact of developmental culture on new product innovation?

- What is the impact of developmental culture on new organizational practice?

- What is the impact of developmental culture on proactivity?

- What is the impact of developmental culture on risk-taking? 


\section{IMacrothink}

- What is the impact of rational culture on new product innovation?

- What is the impact of rational culture on new organizational practice?

- What is the impact of rational culture on proactivity?

- What is the impact of rational culture on risk-taking?

- What is the impact of open culture on new product innovation?

- What is the impact of open culture on new organizational practice?

- What is the impact of open culture on proactivity?

- What is the impact of open culture on risk-taking?

- What is the impact of flexibility/ support or change on new product innovation?

- What is the impact of flexibility/ support or change on new organizational practice?

- What is the impact of flexibility/ support or change on proactivity?

- What is the impact of flexibility/ support or change on risk-taking?

- What is the impact of open communication on new product innovation?

- What is the impact of open communication on new organizational practice?

- What is the impact of open communication on proactivity?

- What is the impact of open communication on risk-taking?

- What is the impact of external orientation on new product innovation?

- What is the impact of external orientation on new organizational practice?

- What is the impact of external orientation on proactivity?

- What is the impact of external orientation on risk-taking?

- What is the impact of teamwork on new product innovation?

- What is the impact of teamwork on new organizational practice?

- What is the impact of teamwork on proactivity?

- What is the impact of teamwork on risk-taking?

\subsection{Significance}

Historically, there are a lot of researches were conducted on organizational culture and entrepreneurial orientation but no one has ever conduct a comparative or nexus research in which organizational culture was measured by teamwork, external orientation, developmental culture, rational culture, clan culture, open culture, open communication, flexibility/ support to change, hierarchical culture (altogether) and entrepreneurial orientation was measured by innovativeness, risk-taking, new organizational practice and proactiveness (altogether). 
This study can benefit organizations in analyzing how different type of organizational culture effect the new product innovation, organizational practice, proactiveness and risk-taking. The organizational culture play a key role in performing work done within the organization. In addition, this study would also be beneficial for executive management of the organization in evaluating the best organizational practice.

\section{Literature Review}

In the background of culture-innovation relations, valuable perceptions remain to be found in an overview of 852 little and medium-sized skill organizations by Mazur, Rószkiewicz and Strzyżewska $(2008,2011)$. The discoveries indicated that the highest level organizations in every one of the three information practice classifications (which can be deciphered as organizations portrayed by a solid information culture) played out the best. What is additionally fascinating, those organizations were overseen by information situated (pioneers of significant level information direction). (Donate, Guadamillas, 2011) additionally battled that imaginative culture will bolster their development rehearses.

Li et al., (2013) inspected both the immediate and circuitous manners by which culture can impact corporate hazard taking. The paper proposes that culture will have a greater amount of an effect when supervisors have more circumspection. What's more, carefulness will in general be more noteworthy in littler firms. Thus, administrators in littler firms ought to be bound to participate in less secure conduct contrasted with their partners in bigger firms (which ordinarily have greater administration control frameworks set up that demonstration to compel administrative conduct).

Naïma Cherchem (2017) look at that in family firms, hierarchical culture develops through a progressing dynamic procedure of intergenerational collaboration. The investigation draws from the Competing Values Framework to look at the degree to which generational inclusion shapes the effects of tribe culture and various leveled culture on Entrepreneurial direction. From a quantitative investigation of 106 family SMEs, the outcomes show that there is no single social way for creating and keeping up long haul family firm's enterprising direction. While tribe culture encourages more significant levels of innovative direction when just a single era is included Li et al., (2013) inspected both the immediate and backhanded manners by which culture can impact corporate hazard taking. The paper recommends that culture will have a greater amount of an effect when supervisors have more caution. Furthermore, watchfulness will in general be more noteworthy in littler firms. Thusly, supervisors in littler firms ought to be bound to participate in more hazardous conduct contrasted with their partners in bigger firms (which ordinarily have greater administration control frameworks set up that demonstration to oblige administrative conduct). (Nordqvist, M. 2010) offers bits of knowledge through the viewpoint of dynamic capacities, which are made by information and thus produce enterprising execution and worth creation. The outcome find that family inactivity relies upon attributes of the privately-owned company culture, where paternalism and enterprising direction impact family latency emphatically and adversely, separately. Family firms from Switzerland and Italy dynamic in the drink business speak to the exact setting. Gursoy (2016) study the targets uncovering the connection between creative culture 
and business endeavor. It expects to discover answers to how inventive culture influences business enterprise, what the connection between imaginative culture and business endeavor is, and what degree creative culture bolsters making new techniques and plans. The investigation discovers that imaginative culture has a huge and constructive outcome on the business undertaking, on total and by its measurements.

Livari (2007) dissected the connection between authoritative culture and the sending of frameworks improvement systems. The outcomes show that the sending of techniques by IS engineers is principally connected with a progressive culture that is arranged toward security, request, and routinization. IT chiefs' basic mentalities of the arrangement of systems in associations with a solid reasonable culture (concentrating on profitability, effectiveness, and objective accomplishment) is additionally important.

Sylvie Laforet (2016) inspects the impacts of hierarchical culture on authoritative advancement execution in family little and medium-sized endeavors. A postal study of family SMEs across areas in the UK is directed. The discoveries show that a paternalistic and originator culture type doesn't positively affect family firm advancement execution, however an enterprising like culture does, for example, one that is remotely situated, adaptable, proactive, and long haul arranged. Essentially, an internal center culture, for example, the organizer culture obstructs advancement; while an outward center culture, for example, an outside direction culture positively affects family firm development execution. This investigation makes significant commitments to the comprehension of hypotheses and practices of development in privately-run companies.

Nazamul Hoque (2013) build up a model of authoritative culture from an Islamic perspective. In the investigation. The striking highlights are confided in Allah, evangelist energy, equity, responsibility, common regard, shared trust, supreme earnestness, dedicated, collaboration, greatness, thoughtful treatment, genuineness and honesty, profound quality, consultative dynamic, information, great conduct, sacrifice, flawless and neatness. The findings of the examination can be utilized as a manual for Islamic hierarchical culture in Muslim nations.

\section{Theoretical Framework}

\subsection{New Product Innovation}

Product modernization is an indispensable undertaking for the cutting edge partnership. The organization's prosperity at new item origination, advancement, and dispatch chooses the destiny of the whole business.

Product advancement can come in three distinct structures. 1) The advancement of another item. 2) An improvement in the exhibition of the current item. 3) Another element to a current item. This development can be in the item's own usefulness, or it can appear as new innovation.

An innovation must separate itself from the opposition and be recognized by in any event one interesting component. This separating highlight ought to be exceptionally pertinent for the client and ought to have the option to be kept up in the long haul. Item advancement 
incorporates the activities, strategies, procedures, and procedures for making gradual upgrades to existing items and administrations. It includes rolling out developmental improvements to the items utilizing the common advancements and hierarchical abilities or another approach to accomplish something.

This recollects gigantic redesigns for specific subtleties, parts and materials, combined programming, convenience, and other utilitarian characteristics. They ought to in like manner deal with a current issue in another and empowering way. Or then again, the thing needs to deal with an absolutely new issue that has risen.

As a thing, headway relates to both the improvement of new things and the improvement of existing things so this improvement can insinuate changes in structure or use of new materials or fragments in the gathering of developed things. The efficiency of these things is affected fundamentally by how much they are truly isolated from fighting decisions. Thing headway and advancement grants associations to build the advantage, pull in new customers, hold existing customers, and strengthen the relationship with their apportionment channels (Keller, 2003). The legitimate heritage of the firm will affect its future decisions as for the business segments where it will work.

For a few organizations effective item advancement is a motor of development (Pauwels, Silva-Risso, Srinivasan, and Hanssens, 2004). This is on the grounds that items with one of a kind and separated highlights give extra an incentive to clients, and in this manner, impact their buying choice. In huge associations that effectively figured out how to manufacture dependable brand names around the world, advancement is turning into their basic practice to make a positive recognition among clients. One of the potential ways to guarantee advancements originates from an association's capacity to concoct quality items and appealing item structures, for example, the instance of an automotive.

\subsection{New Organizational Practice}

In the twenty-first century, associations face numerous new difficulties. The general public and the economy have changed so profoundly that the only remaining century's administration practices and speculations are not, at this point significant. Nearly all that we do today as people or associations expect us to cooperate with huge scope establishments. The new hierarchical structure's writing contends that in a unique business condition, better approaches for getting sorted out are required to guarantee speed, adaptability, and advancement.

In this day and age, the structure, substance, and procedure of work have changed. Work is currently more psychologically perplexing, more group-based, and community-oriented, increasingly reliant on social abilities, progressively subject to innovative fitness in addition to time-constrained and progressively portable and less subject to geology. New work rehearses have been embraced, for example, work pivot, delayering, self-coordinated work-groups, without a moment to spare and all-out quality administration. The outcomes of these hierarchical changes in the firm's execution and expertise requirements are generally observed. 
Utilizing either industry or firm-level information, the majority of these workers show a positive effect of new work rehearses upon efficiency, particularly regarding data advancements. Powers that are fundamentally molding administration rehearses today incorporate the pace of progress, innovation, globalization, decent variety, and social desires. Albeit numerous different factors at last add to the changing examples of work, hierarchical scholars point to two key drivers:

- Increasing pressures on organizations to be progressively serious, nimble, and client centered - to be a "lean undertaking."

- Correspondence and data innovation achievements, particularly portable advances and the Internet that empower workers to be isolated from reality.

Because of these new work rehearses organizations today are nimble and centered around recognizing an incentive from the client's point of view. They are currently more tuned to dynamic serious prerequisites and system, less various leveled in structure and choice authority in addition to less inclined to give long-lasting vocations and employer stability alongside persistently revamping to keep up or increase upper hand.

\subsection{Proactive Behaviour}

Dynamic activity implies responding, yet acting before future circumstances. It implies adjusting to the circumstance as well as trusting that something will occur, taking control and moving things. Dynamic workers typically shouldn't be approached to act and don't require itemized directions. Proactive conduct stands out from other occupation-related practices, for example, a capability that is, meeting unsurprising employment prerequisites, tending to, adjusting to change, and offering help. By different individuals from the association. As to the last viewpoint, versatility comprises of responding to change, yet forcefulness is tied in with causing change. Proactive isn't constrained to extra move execution conduct. Workers can assume a proactive job. Additionally, activities named as sorted out resident activities can be effectively or inactively received. Proactive conduct at work has gotten significant insightful examination consideration in the course of recent years. It has not, be that as it may, rose as an incorporated examination stream in the hierarchical conduct writing. There is no single definition, hypothesis, or measure driving this assemblage of work; rather, specialists have received various methodologies toward recognizing the forerunners and results of proactive conduct, and they have inspected them in various apparently detached writing. Proactive conduct has been conceptualized and estimated in an assortment of ways, a meaning of proactive conduct that catches the quintessence of the different methodologies must be coarse-grained.

\subsection{Risk Taking}

Miller and Friesen (1983) portray chance as a degree acknowledged by top administration for disappointment bringing significant expense. Covin and Slevin (1991) characterize hazard taking as "execution of investment decisions and strategic aims under uncertain conditions". As far as business enterprise, the hazard is given choices, with respect to vulnerability and business under hazard, towards another item, market, procedure, and endeavors (Cornwall 
and Perlman, 1990). To business visionaries, hazard attempted by workers relies upon top organization chance craving. Under vulnerability, the board's level of tolerating disappointment affects ambitious innovator's later choices.

The resistance of vulnerability in the association. In the high hazard taking case, choices and activities are brief and fast, emerging open doors are taken and solid experimentation is liked to definite examination and investigation. In a hazard maintaining a strategic distance from atmosphere, there is a wary, reluctant mindset. Individuals attempt to be "erring on the side of caution". They choose "to rest on the issue". They set up boards and they spread themselves from multiple points of view before settling on a choice (Ekvall, G. 1996).

Risk is characterized as the likelihood of an occasion and its outcomes. Hazard the board is the act of utilizing procedures, techniques, and instruments for dealing with these dangers. Maintaining a business accompanies a wide range of kinds of hazard. A portion of these potential dangers can pulverize a business while others can cause genuine harm that can be expensive and tedious to fix. Business Risk the executives is a subset of hazard the board used to assess the business dangers included if any progressions happen in the business activities, frameworks, and procedure. It centers on recognizing what could turn out badly, assessing which dangers ought to be managed, and actualizing methodologies to manage those dangers. Organizations that have distinguished the dangers will be more ready and have a more financially savvy method of managing them. It recognizes, organizes, and addresses the hazard to limit punishments from startling occurrences, by keeping them on target. It likewise empowers an incorporated reaction to different dangers and encourages a progressively educated hazard based dynamic capacity.

In the event that and when a hazard turns into a reality, a decidedly ready business can limit the effect on income, the lost time and profitability, and the negative effect on clients. The capacity to recognize which dangers represent a danger to effective activities is a key part of vital business arranging. Business dangers are distinguished utilizing different strategies, yet each recognizing procedure depends on a thorough investigation of explicit business exercises that could introduce difficulties to the organization. It ought to be comprehended that proceeding on a similar way for a really long time is a formula for hindered development and falling behind in your industry. The key is in the language structure; facing a challenge is never going to be without peril however facing a determined challenge brings a higher possibility for remunerations. By computing the results you are reducing the expected mischief and expanding your chances of a positive result. Managers are faced with making decisions throughout their work day. Some decisions are routine or easy, while others are complicated and risky. Certain types of people enjoy taking risks, while others prefer stability and are averse to any type of risk. A risk-taker individual is somebody who dangers everything in the desire for accomplishment or acknowledges the more prominent potential for misfortune in choices and endures vulnerability. Be that as it may, it likewise has its own impediments, factors considering a human contribution in dynamic. Human judgment can now and again be founded on past understanding or sheer premonition, which could possibly work consistently. Straightforward blunders or slip-ups can flip around the business. This could likewise happen when at least two individuals are included and they neglect to go to a 
similar comprehension or acknowledge a choice in a confounded perspective/scurry. These constraints block the board from having total affirmation towards the accomplishment of the element's goals.

\subsection{Organization's Culture}

An organization's culture defines the appropriate way to act within the organization. This culture is made up of common beliefs and values that have been established by leaders and communicated in a variety of ways that ultimately shape employee awareness, behavior and understanding. Because the sector and situation are quite different, there is no single cultural model that meets the needs of all organizations

According to (Conrad, 2012) "organizations are embedded in societies and cannot be understood outside of a society's beliefs, values, structures, practices, tension and ways of managing those tensions".. (Schein, 2004) defines organizational culture as "a pattern of shared basic assumptions that was learned by a group as it solved its problems of external adaptation and internal integration that has worked well enough to be considered valid and, therefore, to be taught to new members as the correct way to perceive, think, and feel in relation to those problems."

\subsubsection{Clan Culture}

Clan culture is a type of corporate environment such as a family or group or a tribe that emphasizes the compromise and unity of aims and values. In clan culture on an organization employee's engagement and commitment are considered to promote the ability and loyalty that drive productivity and business success. According to Hill, (2013) Clan culture is based on collaboration, and organizations are more focused on employee value and satisfaction, which leads to increased organizational productivity.

A clan culture is described by benevolence, which is considered to cultivate faithfulness and pledge to the community methodology and family's drawn-out flourishing. Thus, tribe culture is related to a gathering based way to deal with the business enterprise since it emphasizes coordinated effort in the pioneering dynamic and favors compensating people when they share their insight. In view of crafted by Cameron and Quinn (2006), group culture is described by convention and faithfulness. It accentuates attachment and joint effort and urges individuals to grasp the firm's qualities and objectives.

Tribe culture is related with a significant level of trust among the various on-screen characters in an association. More elevated levels of trust will additionally prompt more grounded relational union and dependability, therefore boosting interior joint effort and information trade across various utilitarian limits, which is required to drive a firm's inventiveness. Moreover, an association's accentuation on flexibility encourages "natural structures," which speak to something contrary to robotic and stable structures (Gursoy 2016)

$\mathrm{H}_{1 \mathrm{a}}$ : There is a significant relation between clan culture and new product innovation.

$\mathrm{H}_{1 \mathrm{~b}}$ : There is a significant relation between clan culture and new organizational practice. 
$\mathrm{H}_{1 \mathrm{c}}$ : There is a significant relation between clan culture and proactivity

$\mathrm{H}_{1 \mathrm{~d}}$ There is a significant relation between clan culture and risk-taking.

\subsubsection{Hierarchical Culture}

A hierarchical culture is an organizational typical model based on visibly well-defined corporate stages and structures. In a business environment, hierarchies hinge on structure, rules and top-down control to monitor business practices and actions. Hierarchical culture refers to the management of a consecrated culture according to a standardized structure, which makes its functioning effective and efficient. This type of culture emphases on rules, guidelines, regulations and policies and is more formalized compared to other forms of culture (Hill, 2013).

A hierarchical culture shows an accentuation on inward concentration yet varies through its attention to soundness. It can additionally be described by attention on security and routinization, and it is situated toward control, steadiness, and efficiency (Iivari and Huisman 2007). In progressive societies with brought together structures, the choice authority is normally restricted to one chief or to just a couple of supervisors (Bunderson 2003), which unequivocally influences the preparation of data in an organization.

$\mathrm{H}_{2 \mathrm{a}}$ : There is a significant relation between hierarchical culture and new product innovation.

$\mathrm{H}_{2 b}$ : There is a significant relation between hierarchical culture and new organizational practice.

$\mathrm{H}_{2 \mathrm{c}}$ : There is a significant relation between hierarchical culture and proactivity

$\mathrm{H}_{2 \mathrm{~d}}$ : There is a significant relation between hierarchical culture and risk-taking.

\subsubsection{Developmental Culture}

Developmental culture means the capability to adapt rapidly to changing circumstances. According to Hills (2013), developmental culture is focusing more on bringing creativity and innovation in the organization. These qualities are relied upon to instigate inflexibility inside the family firm's structure and diminish hierarchical flexibility and decentralization, which are crucial attributes when family firm is little estimated, in another word when there is just a single era included. This flexibility empowers family firms to misuse enterprising chances (Zahra et al., 2008). Interestingly, centralization and formalization esteems have been found to prompt lower levels of advancement, proactivity, and hazard taking exercises. Subsequently, the various leveled culture perspectives stifle family firms in their efforts to seek after enterprising exercises (Zahra et al., 2004) when just a single era is included.

$\mathrm{H}_{3 \mathrm{a}}$ : There is a significant relation between developmental culture and new product innovation.

$\mathrm{H}_{3 \mathrm{~b}}$ : There is a significant relation between developmental culture and new organizational practice. 
$\mathrm{H}_{3 \mathrm{c}}$ : There is a significant relation between developmental culture and proactivity

$\mathrm{H}_{3 \mathrm{~d}}$ : There is a significant relation between developmental culture and risk-taking.

\subsubsection{Rational Culture}

Rational culture is characterized by significance on steadiness and an outer concentration with yield, efficiency, and target accomplishment as its essential qualities (Iivari and Huisman 2007) Employees are urged to set troublesome objectives and endeavor to accomplish them. Worker execution is firmly observed and frequently legitimately remunerated or rebuffed. The accentuation on singular execution is thought to prompt more noteworthy accomplishment for the individual representative and, thus, more prominent accomplishment for the association.

Objective culture is firmly objective arranged, this majorly affects how the hierarchical individuals connect. Coordinated effort and close reconciliation of various divisions inside associations are considered as a focal component in encouraging EO (Morris et al. 2007). Contingent upon the hidden authoritative culture, an exceptional mix may prompt concentrated social binds with a negative impact on an association's imaginativeness (Sethi, Smith, and Park 2001).

$\mathrm{H}_{4 \mathrm{a}}$ : There is a significant relation between rational culture and new product innovation.

$\mathrm{H}_{4 \mathrm{~b}}$ : There is a significant relation between rational culture and new organizational practice.

$\mathrm{H}_{4 \mathrm{c}}$ : There is a significant relation between rational culture and proactivity

$\mathrm{H}_{4 \mathrm{~d}}$ : There is a significant relation between rational culture and risk-taking.

\subsubsection{Open Culture}

An open culture is one that even enormous associations endeavor to accomplish so as to develop. Google touts an open culture and credits the organization's prosperity to its way of life. An open culture can get dynamic reasoning, a drawn out vision, headway, and sympathy for one another, all of which can drive the association fast. An open culture, which depends on enterprising direction, acts family in real life in order to emphatically influence asset recombination forms. A pioneering direction (as far as creativity, genius animation and hazard taking) may permit a firm to beat the firmness trap of hierarchical abilities by refreshing them over and again. As nature changes, hierarchical adjustment turns out to be increasingly vital, and past examples and practices less proper.

An open culture encourages innovative activity, and along these lines decidedly influence the recombination of inside and outside assets. With stable degrees of information and shut culture, the firm can't encourage change and creates an incentive after some time.

$\mathrm{H}_{5 \mathrm{a}}$ : There is a significant relation between open culture and new product innovation.

$\mathrm{H}_{5 \mathrm{~b}}$ : There is a significant relation between open culture and new organizational practice.

$\mathrm{H}_{5 \mathrm{c}}$ There is a significant relation between open culture and proactivity 
$\mathrm{H}_{5 \mathrm{~d}}$ : There is a significant relation between open culture and risk-taking.

\subsubsection{Flexibility/ Support or Change}

Flexibility is the ability to conform to momentary change rapidly and serenely, so worker can manage unforeseen issues or errands viably. Flexibility can be characterized as the association adjusting to estimate, piece, responsiveness, and the individuals, their data sources, and costs required to accomplish hierarchical targets and objectives. Hierarchical adaptability can likewise be characterized when work completes, where it completes, and how work completes.

Flexibility mirrors an association's capacity to adjust to changing conditions and necessities and is influenced by issues, for example, preparing, the board, and re-appropriating. The ability of an association to utilize client centered individuals at each level and assemble forms easy to execute as well as adaptable enough to endure and contend successfully with an evolving domain.

Flexibility speaks to the capacity of an assembling framework to adjust to some expanded errands of creation, therefore to guarantee a financial proficiency - the compatibility time/cost ought to be ideal, with inconsequential structure changes inside a significant stretch of time. The focal job of adaptability is to allow the endurance and the accomplishment of the associations in a tempestuous condition, which is normal for the new world propensities. The more adaptable the association turns into, the better it reacts to the change. Firms, which are flexible, encourage imagination, developments, and speed, all these being remembered for the authoritative and coordination forms. In brisk change conditions, adaptability is an upper hand. An association should confront the two dangers and inalienable open doors in a dubious future and in an insecure situation. Flexibility and promptitude are the characteristics of authoritative achievement and the need should be flexible is a basic of rivalry.

$\mathrm{H}_{6 \mathrm{a}}$ There is a significant relation between flexibility/ support or change and new product innovation.

$\mathrm{H}_{6 \mathrm{~b}}$ : There is a significant relation between flexibility/ support or change and new organizational practice.

$\mathrm{H}_{6 \mathrm{c}}$ : There is a significant relation between flexibility/ support or change and proactivity

$\mathrm{H}_{6 \mathrm{~d}}$ : There is a significant relation between flexibility/ support or change and risk-taking.

\subsubsection{Open Communication}

Open communication implies is the place workers are urged to share their considerations and concerns, both great and terrible, without the concern of counter from the board when the criticism is awful. Open communication is a significant instrument for organizations, to improve proficiency and viability among the representatives. Open communication happens when all gatherings can communicate thoughts to each other, for example, in a discussion or discussion. Open communication is a significant instrument business, colleges, charitable associations, and different associations can use to improve their gatherings' proficiency and 
adequacy. Associations that need to remain current with their structures and rehearses and those that want to consistently learn should actualize open correspondence rehearses. Open communication enables associations to improve. Data isn't sifted through a few degrees of the board, yet rather, it is separated through fewer levels. It is more straightforward from the upper levels to the lower levels and the other way around. The struggle is all the more tranquility and properly managed when all degrees of partners realize what is happening inside the association and the future course of the association's exercises.

\subsubsection{External Orientation}

An external cultural orientation (EO) is guided by the clients and other market or outer powers. It centers on the get-together of market or outer data to make better experiences into new and developing open doors for the firm. An external cultural orientation includes a restricted pre-investigation of the association where the hands-on work task will be completed and the division in which the association is dynamic. The goal of the outside direction is to get the data and bits of knowledge required for an effective admission meeting.

An external cultural orientation altogether develops a solid culture inside the association to propel a worker for information sharing and improving capacities to decide the open doors for the association. An external cultural orientation dependent on advertising course and the company's flexibility with the outrageous circumstance and neighboring association with the clients and adaptability by means of commonality to showcase is likewise fundamental for reasonable advancement execution. An external cultural orientation is a key factor to expand the imaginative hierarchical execution depicted the outside direction as satisfying current and future prerequisites of possible clients just as estimating the adjustment in the client's desires and sharing concerning data inside the organization.

$\mathrm{H}_{8 \mathrm{a}}$ : There is a significant relation between external orientation and new product innovation.

$\mathrm{H}_{8 \mathrm{~b}}$ : There is a significant relation between external orientation and new organizational practice.

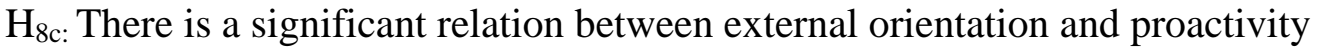

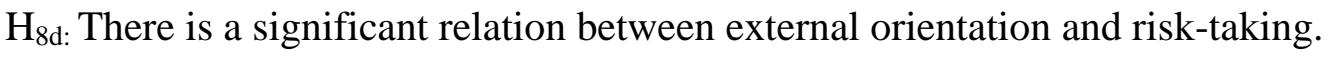

\subsubsection{Team-work}

Team work is a gathering of individuals with various abilities and various assignments, who cooperate on a typical venture, administration, or objective, with a lattice of capacities and shared help. Team work is working consciously and successfully with a gathering and doing your offer. Numerous fundamental character qualities, for example, correspondence, discretion, and lowliness, bolster an individual's capacity to take a shot at a group. Team work is more than coexisting with individuals. The way to being a decent cooperative person is the capacity to put a gathering's needs over your own.

Team work includes a lot of related exercises performed by people who team up toward a shared objective. Team work includes a lot of assignments and exercises performed by people 


\section{Macrothink}

Business and Economic Research ISSN 2162-4860 2020, Vol. 10, No. 3

who work together with one another to accomplish a typical goal. That goal can be making an item, conveying assistance, composing a report, or settling on a choice. Team work contrasts from singular work in that it includes shared duty regarding the ultimate result. Team work is significant in an association since it furnishes workers with a chance to bond with each other, which improves relations among them. Team work expands the responsibility of each individual from the group, particularly when working under individuals who deserve a ton of admiration inside the business. Team work holds an exceptionally significant spot in associations, with Team work among representatives just as significant as a coordinated effort among individuals from a brandishing group.

$\mathrm{H}_{9 \mathrm{a}}$ : There is a significant relation between teamwork and new product innovation.

$\mathrm{H}_{9 b}$ : There is a significant relation between teamwork and new organizational practice.

$\mathrm{H}_{9 \mathrm{c}}$ : There is a significant relation between teamwork and proactivity

$\mathrm{H}_{9 \mathrm{~d}}$ There is a significant relation between teamwork and risk-taking.

\subsection{Research Model}

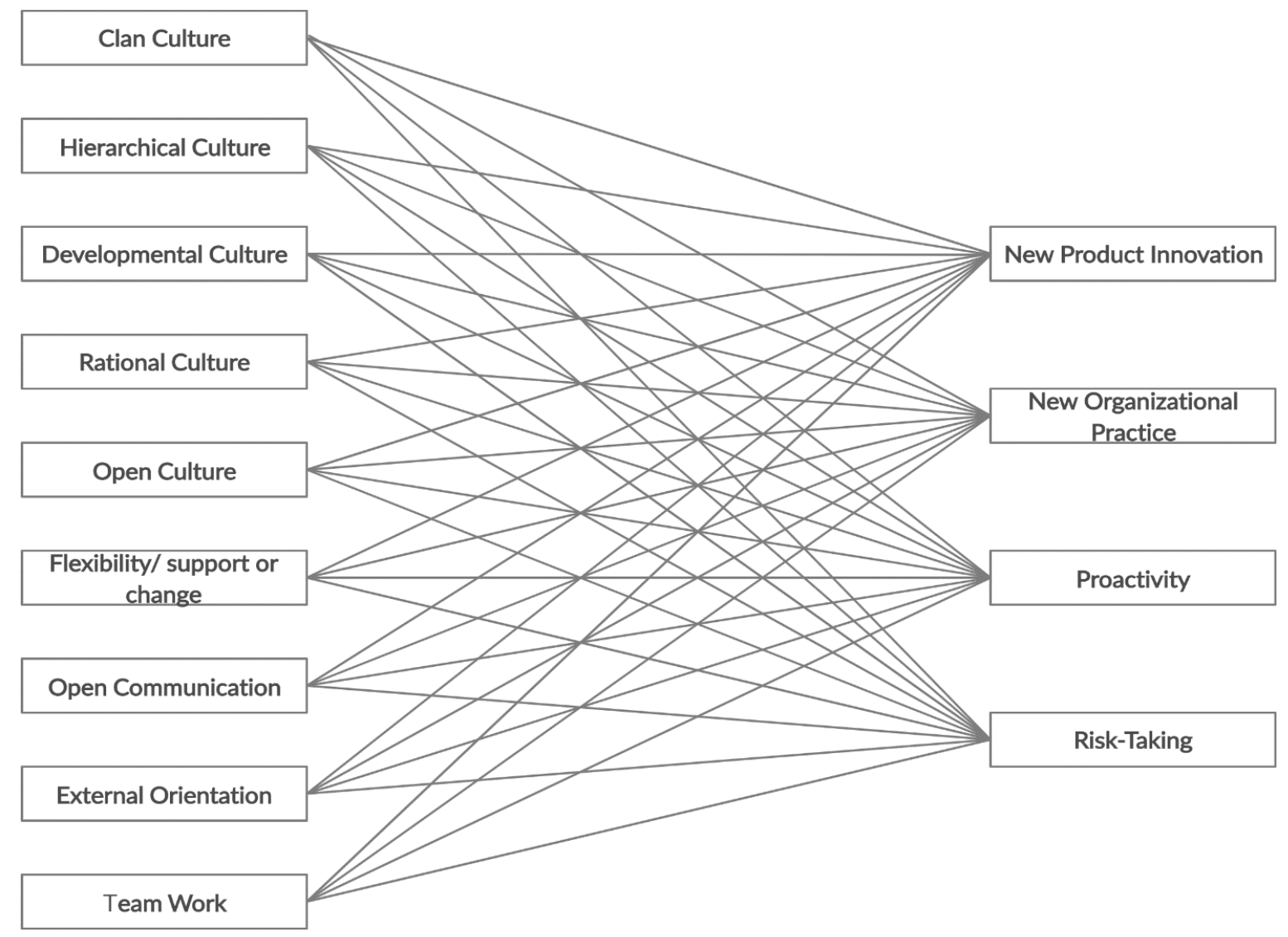

\section{Methodology}

In this section we will discuss sampling, sources of data, statistical tools, framework, hypotheses, etc. related to our topic. 


\subsection{Sampling}

Population for this research was the employees who are working in different organizations. The sample chosen for this research paper is 300 out of 320. In this research project, primary data had been collected by using survey questionnaires method. Questionnaires were distributed to the employees who are currently working in any organization.

The data gathered from the questionnaires were entered into Smart PLS where PLS Algorithm and bootstrapping has been applied to explore the effect of organizational culture on new product innovation, new organizational practice, proactivity and risk-taking of the employees working in different organizations. To conduct the responses, individuals who are working as teacher's in different privately owned institutes of Karachi are selected for the analysis of the results.

\subsection{Measurement}

The instruments for this research is adapted from different researches. The variables organizational culture, an external orientation, flexibility, open culture, open communication, new product innovation and new organizational practice is adapted from Laforet, S. (2016). The variable clan culture and hierarchical culture is adapted from Cherchem, N. (2017). The variable teamwork is adapted from Shahbaz, M. (2017). The variable rational culture and developmental culture is adapted from Guven, B. (2016) and the variables proactivity and risk-taking is adpted from Flatten, T. C. (2015).

\section{Data Analysis}

Survey questionnaires were used to gather data that is now tested by the help Smart PLS 3 software (Ringle et al., 2005). Numerous techniques including, Descriptive analysis, EFA, CFA, PLS Algorithm and SEM are conducted in order to obtain results and to finalize this research. And for the purpose of testing path co-efficient and loading Bootstrapping is one of the best techniques (Chin, 1998 and Gil-Garcia, 2008).

\subsection{Data Screening}

Data Screening is a process that makes sure your data is useable, reliable and valid for further processing it is done before applying different statistical techniques. Data screening includes analysis of missing values in the gathered data along with data coding and outliers among the responses collected from the respondents.

\subsection{Structural Equation Modeling}

Structural equation modeling (SEM) is a combination of different statistical analysis technique used to analyze the structural association of the study. It is a combination of two different analysis which is factor examination and regression investigation which is used to analyze the relation in between measure and latent variable as well as high aspects in a lower structures environment (Dijkstra \& Henseler, 2015).

Partial Least Square-SEM modeling of structural equation is appropriate for the study of a compound framework used in a research (Henseler et al., 2014). However, Structural 


\section{IIMacrothink}

Business and Economic Research

ISSN 2162-4860

2020, Vol. 10, No. 3

Equation Modeling technique is used to examine the collected data (Ringle, Wende, \&Becker, 2014).

\subsection{Descriptive Analysis}

Table 1. Respondents' Profile

\begin{tabular}{|l|l|l|l|}
\hline Variable & Category & Frequency & Percentage \\
\hline \multirow{4}{*}{ Age } & $20-30$ & 221 & $73.7 \%$ \\
\cline { 2 - 4 } & $31-40$ & 67 & 22.3 \\
\cline { 2 - 4 } & $41-50$ & 10 & 3.3 \\
\cline { 2 - 4 } & Above 50 & 2 & 0.7 \\
\hline \multirow{4}{*}{ Gender } & Male & 187 & 62.3 \\
\cline { 2 - 4 } & Female & 113 & 37.7 \\
\hline \multirow{5}{*}{ Working Experience } & 0-5 Years & 218 & 72.7 \\
\cline { 2 - 4 } & 6-10 Years & 56 & 18.7 \\
\cline { 2 - 4 } & 11-15 Years & 21 & 7 \\
\cline { 2 - 4 } & Above 15 Years & 5 & 1.7 \\
\hline
\end{tabular}

To change gathered data into information that can easily be understand and help researchers to explain their findings. Descriptive analysis helps researchers to rearrangeor interpret the responses as per their results (Zikmund, 2003). Descriptive Analysis consists of mean, Median and Mode. Mean shows the average of the data. Median is the middle value of the data however mode is the values that appear the most in the gathered data.

The sample of targeted population represented responses from various individuals, out of the total 300 respondents in which 187 of the respondents were males contributing about $62.3 \%$ of the total sample size whereas 113 of the females are making up to 37.7\%. 221 of the employee's aged between 20-30 years making $73.7 \%$ while 67 employees are aged between $31-40$ years contributing $22.3 \%, 10$ employees are aged between 41 to 50 years comprising of $3.3 \%$ whereas employees above 50 are 2 contributing $0.7 \%$.

The experience levels also varied throughout the responses. As divided on the basis of working experience; 218of the respondents has an experience about 0-5 years contributing $72.7 \%, 56$ respondents has an experience of 6-10 years contributing about $18.7 \%$ whereas, 21 $\& 5$ respondents has an experience of $11-15$ years \& above 50 years contributing $7 \%$ \& $1.7 \%$ respectively. 


\section{Macrothink}

Business and Economic Research

ISSN 2162-4860

Table 2. Descriptive Statistic

2020, Vol. 10, No. 3

\begin{tabular}{|c|c|c|c|c|c|c|}
\hline \multirow{2}{*}{$\begin{array}{ll}\text { Variables and } \\
\text { Factors }\end{array}$} & \multirow[t]{2}{*}{ Questions } & \multicolumn{2}{|c|}{ Descriptive Stats } & \multicolumn{3}{|c|}{ Confirmatory Factor Analysis } \\
\hline & & Mean & $\begin{array}{l}\text { Standard } \\
\text { Deviation }\end{array}$ & $\begin{array}{l}\text { Outer } \\
\text { Loading }\end{array}$ & Stats & Values \\
\hline \multirow[t]{6}{*}{$\begin{array}{l}\text { Clan } \\
\text { Culture }\end{array}$} & $\begin{array}{l}\text { The organization is a very personal place. It is like an extended family. People seem to share a } \\
\text { lot of themselves. }\end{array}$ & 0.866 & 0.020 & 0.864 & 42.215 & 0.000 \\
\hline & $\begin{array}{l}\text { The leadership in the organization is generally considered to exemplify mentoring, facilitating } \\
\text { or nurturing. }\end{array}$ & 0.909 & 0.013 & 0.909 & 70.731 & 0.000 \\
\hline & $\begin{array}{l}\text { The management style in the organization is characterized by teamwork, consensus and } \\
\text { participation. }\end{array}$ & 0.906 & 0.012 & 0.906 & 74.726 & 0.000 \\
\hline & $\begin{array}{l}\text { The glue that holds the organization together is loyalty and mutual trust. Commitment to this } \\
\text { organization runs high. }\end{array}$ & 0.915 & 0.012 & 0.915 & 77.012 & 0.000 \\
\hline & $\begin{array}{l}\text { The organization emphasizes human development. High trust, openness, and participation } \\
\text { persist. }\end{array}$ & 0.985 & 0.014 & 0.895 & 62.095 & 0.000 \\
\hline & $\begin{array}{l}\text { The organization defines success on the basis of the development of human resources, } \\
\text { teamwork, employee commitment, and concern for people. }\end{array}$ & 0.908 & 0.013 & 0.908 & 70.414 & 0.000 \\
\hline \multirow[t]{6}{*}{$\begin{array}{l}\text { Hierarchical } \\
\text { Culture }\end{array}$} & $\begin{array}{l}\text { The organization is a very controlled and structured place. Formal procedures generally govern } \\
\text { what people do. }\end{array}$ & 0.824 & 0.023 & 0.842 & 36.336 & 0.000 \\
\hline & $\begin{array}{l}\text { The leadership in the organization is generally considered to exemplify coordinating, organizing } \\
\text { or smooth - running and efficiency. }\end{array}$ & 0.864 & 0.017 & 0.866 & 51.977 & 0.000 \\
\hline & $\begin{array}{l}\text { The management style in the organization is characterized by security of employment, } \\
\text { conformity, predictability, and stability in relationships. }\end{array}$ & 0.900 & 0.014 & 0.901 & 65.908 & 0.000 \\
\hline & $\begin{array}{l}\text { The glue that holds the organization together is formal rules and policies. Maintaining a } \\
\text { smoothly running organization is important. }\end{array}$ & 0.875 & 0.021 & 0.876 & 41.760 & 0.000 \\
\hline & $\begin{array}{l}\text { The organization emphasizes permanence and stability. Efficiency, control, and smooth } \\
\text { operations are important. }\end{array}$ & 0.880 & 0.017 & 0.880 & 52.032 & 0.000 \\
\hline & $\begin{array}{l}\text { The organization defines success on the basis of efficiency. Dependable delivery, smooth } \\
\text { scheduling and low-cost production are critical. }\end{array}$ & 0.850 & 0.022 & 0.850 & 38.348 & 0.000 \\
\hline \multirow[t]{3}{*}{$\begin{array}{l}\text { Developmental } \\
\text { Culture }\end{array}$} & $\begin{array}{l}\text { The company I work in is a very dynamic and entrepreneurial place. People are willing to stick } \\
\text { their necks out and take risks. }\end{array}$ & 0.893 & 0.015 & 0.892 & 61.499 & 0.000 \\
\hline & $\begin{array}{l}\text { The glue that holds the company I work in together is commitment to innovation and } \\
\text { development. There is an emphasis on being first with products and services. }\end{array}$ & 0.894 & 0.015 & 0.895 & 60.922 & 0.000 \\
\hline & $\begin{array}{l}\text { The company I work in emphasizes growth through acquiring new resources. Acquiring new } \\
\text { products/services to meet new challenges is important. }\end{array}$ & 0.925 & 0.009 & 0.924 & $\begin{array}{l}108.09 \\
5\end{array}$ & 0.000 \\
\hline \multirow[t]{3}{*}{$\begin{array}{l}\text { Rational } \\
\text { Culture }\end{array}$} & $\begin{array}{l}\text { The company I work in is a very production-oriented place. People are concerned with getting } \\
\text { the job done and are not very personally involved }\end{array}$ & 0.885 & 0.019 & 0.885 & 46.560 & 0.000 \\
\hline & $\begin{array}{l}\text { The glue that holds the company I work in together is an emphasis on tasks and goal } \\
\text { accomplishment. A production and achievement orientation is commonly shared. }\end{array}$ & 0.924 & 0.011 & 0.923 & 82.608 & 0.000 \\
\hline & $\begin{array}{l}\text { The company I work in emphasizes competitive actions, outcomes, and achievement. } \\
\text { Accomplishing measurable goals is important. }\end{array}$ & 0.904 & 0.015 & 0.904 & 61.676 & 0.000 \\
\hline Open & This company is flexible and adaptable in how it deals with difficulties. & 0.876 & 0.018 & 0.876 & 48.333 & 0.000 \\
\hline
\end{tabular}




\section{Macrothink Institute}

Business and Economic Research

ISSN 2162-4860

2020, Vol. 10, No. 3

\begin{tabular}{|l|l|} 
Culture & This company approaches problems with a positive mind set Members of this company are
\end{tabular} always able to help each other when the need arises.

This company knows it has the power to solve major problem.

Flexibility/

This company when faced with difficulties it works together effectively

\begin{tabular}{l|l|} 
& Informs employees regarding technological changes on a regular basis. \\
\cline { 2 - 3 } Support of change & This firm is aggressively pursuing emerging business opportunities.
\end{tabular}

Managers ask employees if there was a better way to do things.

This firm is committed to providing training to employees.

This firm is devoted for utilization of innovative technology.

The firm approaches problems with a positive mindset

The firm knows it has the power to solve major problems.

Informs employees regarding change thro' bulletins/teleconferences/others.

This company aggressively pursuing emerging business opportunities.

Makes managers/family members an accountable for change.

This company is committed to training.

This company is committed to utilization of technology.

This company recognizes where its greatest assets were.

Open

We regularly talk about things that concern us.

\begin{tabular}{l|l} 
Communication & We take time to listen to each other. \\
\cline { 2 - 2 } & We are fin wih
\end{tabular}

We are frank with each other.

There is open communication in the organization.

Everyone has the chance to express their opinion.

Team members maintain a high level of idea of exchange.

Employees and functional managers are supportive to each other.

Management encourages experimental mind-set and risk taking.

External

This firm tracks changes in its markets on a regular basis.

Orientation

This firm is preferably working with the key customers and learning from them.

The firm values are learning from the activities of its competitors.

This firm pays attention to building relationships with external stakeholders.

This company values working with key customers and learning from them.

This company values working with key suppliers and learning from them.

This company values learning from the actions of its competitors

The firm values are working with an external agent.

Teamwork

There is a lot of group spirit in this organization.

Employees work well with each other.

We all know each other well.

We have social gatherings where everyone in the company comes together.

Management is friendly and approachable.

We value being a team player.

Non-family employees are trusted as much as family employees.

We value consensus in making key decisions.

Creating and preserving clear and explicit practices are important to us

\begin{tabular}{|l|l|l|l|l|}
\hline 0.917 & 0.013 & 0.918 & 73.424 & $\mathbf{0 . 0 0 0}$ \\
\hline 0.883 & 0.018 & 0.884 & 49.388 & $\mathbf{0 . 0 0 0}$ \\
\hline 0.909 & 0.011 & 0.908 & 81.610 & $\mathbf{0 . 0 0 0}$ \\
\hline 0.772 & 0.026 & 0.770 & 29.929 & $\mathbf{0 . 0 0 0}$ \\
\hline 0.768 & 0.028 & 0.766 & 27.523 & $\mathbf{0 . 0 0 0}$ \\
\hline 0.826 & 0.026 & 0.825 & 32.079 & $\mathbf{0 . 0 0 0}$ \\
\hline 0.867 & 0.018 & 0.867 & 47.319 & $\mathbf{0 . 0 0 0}$ \\
\hline 0.879 & 0.015 & 0.879 & 59.050 & $\mathbf{0 . 0 0 0}$ \\
\hline 0.857 & 0.019 & 0.856 & 45.577 & $\mathbf{0 . 0 0 0}$ \\
\hline 0.845 & 0.024 & 0.844 & 35.004 & $\mathbf{0 . 0 0 0}$ \\
\hline 0.851 & 0.020 & 0.850 & 41.926 & $\mathbf{0 . 0 0 0}$ \\
\hline 0.840 & 0.020 & 0.39 & 41.409 & $\mathbf{0 . 0 0 0}$ \\
\hline 0.815 & 0.023 & 0.816 & 35.055 & $\mathbf{0 . 0 0 0}$ \\
\hline 0.825 & 0.027 & 0.826 & 30.137 & $\mathbf{0 . 0 0 0}$ \\
\hline 0.858 & 0.018 & 0.857 & 46.506 & $\mathbf{0 . 0 0 0}$ \\
\hline 0.839 & 0.020 & 0.838 & 42.152 & $\mathbf{0 . 0 0 0}$ \\
\hline 0.846 & 0.023 & 0.846 & 37.077 & $\mathbf{0 . 0 0 0}$ \\
\hline 0.906 & 0.013 & 0.906 & 72.019 & $\mathbf{0 . 0 0 0}$ \\
\hline 0.864 & 0.020 & 0.863 & 42.697 & $\mathbf{0 . 0 0 0}$ \\
\hline 0.915 & 0.011 & 0.914 & 84.179 & $\mathbf{0 . 0 0 0}$ \\
\hline 0.916 & 0.010 & 0.916 & 94.703 & $\mathbf{0 . 0 0 0}$ \\
\hline 0.886 & 0.017 & 0.886 & 53.512 & $\mathbf{0 . 0 0 0}$ \\
\hline 0.880 & 0.018 & 0.880 & 49.639 & $\mathbf{0 . 0 0 0}$ \\
\hline 0.855 & 0.022 & 0.885 & 39.115 & $\mathbf{0 . 0 0 0}$ \\
\hline 0.850 & 0.019 & 0.850 & 45.885 & $\mathbf{0 . 0 0 0}$ \\
\hline 0.858 & 0.022 & 0.859 & 38.964 & $\mathbf{0 . 0 0 0}$ \\
\hline 0.861 & 0.017 & 0.860 & 51.422 & $\mathbf{0 . 0 0 0}$ \\
\hline 0.841 & 0.024 & 0.841 & 34.538 & $\mathbf{0 . 0 0 0}$ \\
\hline 0.878 & 0.015 & 0.877 & 59.261 & $\mathbf{0 . 0 0 0}$ \\
\hline 0.881 & 0.015 & 0.880 & 58.319 & $\mathbf{0 . 0 0 0}$ \\
\hline 0.856 & 0.019 & 0.856 & 44.201 & $\mathbf{0 . 0 0 0}$ \\
\hline 0.845 & 0.022 & 0.846 & 37.761 & $\mathbf{0 . 0 0 0}$ \\
\hline 0.878 & 0.016 & 0.877 & 55.869 & $\mathbf{0 . 0 0 0}$ \\
\hline 0.892 & 0.013 & 0.891 & 69.420 & $\mathbf{0 . 0 0 0}$ \\
\hline 0.883 & 0.017 & 0.883 & 53.021 & $\mathbf{0 . 0 0 0}$ \\
\hline 0.853 & 0.020 & 0.853 & 43.611 & $\mathbf{0 . 0 0 0}$ \\
\hline 0.897 & 0.014 & 0.897 & 64.247 & $\mathbf{0 . 0 0 0}$ \\
\hline 0.895 & 0.015 & 0.895 & 58.190 & $\mathbf{0 . 0 0 0}$ \\
\hline 0.854 & 0.020 & 0.855 & 42.170 & $\mathbf{0 . 0 0 0}$ \\
\hline 0.836 & 0.027 & 0.837 & 31.092 & $\mathbf{0 . 0 0 0}$ \\
\hline 0.869 & 0.019 & 0.868 & 46.102 & $\mathbf{0 . 0 0 0}$ \\
\hline & & & & \\
\hline
\end{tabular}




\section{Macrothink Institute}

Business and Economic Research

ISSN 2162-4860

2020, Vol. 10, No. 3

\begin{tabular}{|c|c|c|c|c|c|c|}
\hline \multirow[t]{7}{*}{$\begin{array}{l}\text { New Product } \\
\text { Innovation }\end{array}$} & $\begin{array}{l}\text { In developing new products adhering to product specifications and minimizing experimentation } \\
\text { is not at all important. }\end{array}$ & 0.778 & 0.033 & 0.779 & 23.901 & 0.000 \\
\hline & Our customers provide specifications for new products & 0.848 & 0.018 & 0.848 & 46.131 & 0.000 \\
\hline & The company's growth rate of sales has increased as a result of introducing new product/service. & 0.854 & 0.020 & 0.853 & 42.776 & 0.000 \\
\hline & Paying attention to product specification during product development is essential. & 0.854 & 0.018 & 0.854 & 48.404 & 0.000 \\
\hline & $\begin{array}{l}\text { Management actively responds to the adoption of "new ways of doing things" by main } \\
\text { competitors. }\end{array}$ & 0.880 & 0.017 & 0.879 & 51.200 & 0.000 \\
\hline & We are willing to try new ways of doing things and seek unusual, novel solutions. & 0.887 & 0.013 & 0.886 & 68.123 & 0.000 \\
\hline & We encourage people to think and behave in original and novel ways. & 0.836 & 0.022 & 0.835 & 38.770 & 0.000 \\
\hline \multirow{7}{*}{$\begin{array}{l}\text { New } \\
\text { Organizational } \\
\text { Practice }\end{array}$} & $\begin{array}{l}\text { Implementation of new business concepts and practices will enhance employee's innovation } \\
\text { skills. }\end{array}$ & 0.838 & 0.033 & 0.838 & 38.064 & 0.000 \\
\hline & Changing organizational structure is significant to promote organizational innovation. & 0.858 & 0.015 & 0.858 & 41.379 & 0.000 \\
\hline & $\begin{array}{l}\text { Introduce technology innovation programs to employees will boost the organizational } \\
\text { innovation. }\end{array}$ & 0.889 & 0.020 & 0.889 & 60.248 & 0.000 \\
\hline & My organization is being first in industry to develop innovative management systems. & 0.827 & 0.018 & 0.827 & 36.703 & 0.000 \\
\hline & My organization is being first to introduce new business concepts and practices. & 0.835 & 0.017 & 0.835 & 41.462 & 0.000 \\
\hline & Changing organizational structure significantly to promote innovation. & 0.869 & 0.013 & 0.869 & 52.565 & 0.000 \\
\hline & Introduce innovative HRM programmes to spur creativity and innovation. & 0.870 & 0.022 & 0.870 & 53.394 & 0.000 \\
\hline \multirow[t]{3}{*}{ Proactivity } & $\begin{array}{l}\text { In general, the top managers of our organization favor a strong emphasis on research and } \\
\text { development, technological leadership, and innovations. }\end{array}$ & 0.914 & 0.012 & 0.913 & 77.123 & 0.000 \\
\hline & $\begin{array}{l}\text { In the past five years, our organization has marketed a large variety of new lines of products or } \\
\text { services. }\end{array}$ & 0.914 & 0.012 & 0.914 & 78.112 & 0.000 \\
\hline & $\begin{array}{l}\text { In the past five years, changes in our products or service lines have been mostly of a minor } \\
\text { nature. }\end{array}$ & 0.879 & 0.018 & 0.879 & 47.567 & 0.000 \\
\hline \multirow[t]{3}{*}{ Risk-Taking } & $\begin{array}{l}\text { In general, the top managers of my organization have a strong propensity for high-risk projects } \\
\text { (with chances of very high return). }\end{array}$ & 0.917 & 0.012 & 0.916 & 77.663 & 0.000 \\
\hline & $\begin{array}{l}\text { The top managers believe, owing to the nature of the environment, that bold, wide-ranging acts } \\
\text { are necessary to achieve our organization objectives. }\end{array}$ & 0.930 & 0.011 & 0.930 & 82.405 & 0.000 \\
\hline & $\begin{array}{l}\text { When there is uncertainty, our organization typically adopts a "wait-and-see" posture in order to } \\
\text { minimize the probability of making costly decisions. }\end{array}$ & 0.876 & 0.020 & 0.875 & 42.858 & 0.000 \\
\hline
\end{tabular}




\subsubsection{Structural Equation Modeling}

To test the examination speculation we have utilized the basic condition model (SEM) though the testing has been experienced Smart PLS programming. Besides, to assess the backhanded and direct impacts of the considerable number of builds the testing was finished. The utilization of (SEM) basic condition model has been seen to be the first technique that has been utilized underneath various relapse models and strategies (Barron and Kenny, 1986). It used to assess the basic connection between exogenous and endogenous factors. It incorporates factor examination and multivariate investigation. Besides, the condition of relapse focuses on disclosing each build to survey the circumstances and logical results relationship while the entirety of the components in the causal model could exhibit their circumstances and logical results at a specific time. Similarly, utilizing this model guarantees to apply the method of bootstrapping which has been seen as sensible for both little and enormous example measures and doesn't require any sort of circuitous impact (Hayes, 2013). So as to check all immediate and circuitous impacts, a procedure has been executed which is known as bootstrapping (Shrout \& Bolger, 2002).

\subsubsection{Measurement of Outer Model}

The objective of the proportion of fit in the estimation model is to learn about the dependability and legitimacy of the instrument and to check its unwavering quality and legitimacy we play out a trial of merged legitimacy and discriminant legitimacy in programming naming Smart PLS.

Table 3. Composite Reliability

\begin{tabular}{|l|l|}
\hline & Composite Reliability \\
\hline Clan Culture & 0.962 \\
\hline Developmental Culture & 0.931 \\
\hline External Orientation & 0.957 \\
\hline Flexibility & 0.967 \\
\hline Hierarchical Culture & 0.948 \\
\hline New Organizational Practice & 0.950 \\
\hline New Product Innovation_- & 0.947 \\
\hline Open Communication & 0.966 \\
\hline Open Culture & 0.943 \\
\hline Proactivity & 0.930 \\
\hline Rational Culture & 0.931 \\
\hline
\end{tabular}

Reliability suggests the steadiness of poll results. For a comparative objective populace, at whatever point the examiner reutilizes the poll it will give a comparative result. It shows inside consistency and repeatability of the study are high. The essential measure for resolute quality is to keep up a vital good ways from shamefulness in research. As such, it will in general be improved by testing the interest system and examination, as is finished using various exploration and assessment strategies or various scientists. This additionally fuses the constancy and authenticity of the investigation.

Reliability of the estimation instruments was assessed utilizing composite dependability. All 
the qualities were over the ordinarily utilized limit esteem for example 0.70 . This is the acknowledged unwavering quality worth range. Estimation of unwavering quality should be possible by the level of consistency that lies among different factors (Hair, 2010).

\subsubsection{Factor Loadings Significant}

Table of descriptive statistics also mentioned loadings used in (CFA) confirmatory factor analysis. Construct with the loading of .5 are consider as strong loading variables whereas the constructs with the loading of below .5 are considered as less are better to be removed from the table.

\subsubsection{Convergent Validity}

For the calculation of items of individual reliability as proposed by Tabachnick and Fidell (2007) a Partial Least square Algorithm is performed. In this the range is greater than 0.5 moreover, all the items involve in this study have the loadings above 0.5 as shown in table that is measurement model results. Moreover, these techniques are the part of PLS Algorithm that help to determine the convergent validity of our measured framework (Fornell \& Larcker, 1981), Cronbach's alpha, composite reliability and AVE.

As the table shows that all the values of Cronbach's alpha is greater than 0.7 (Cronbach, 1951) which indicates that all the variables are reliable, Secondly, all the variables also as per the composite reliability requirement which says that all the values must be greater than 0.7 (Nunnally, 1978). Additionally, for the purpose of analyzing the convergent validity Fornell and Larcker (1981) suggested that the value of AVE should be greater than 0.5 and table of this study represent all values which are greater than 0.5 showing that the considered scales were appropriate to explain the variable.

Table 4. Convergent Validity

\begin{tabular}{|l|l|l|l|l|}
\hline Constructs & Loadings & Cronbach's & Composite Reliability & Average Variance Extracted \\
\hline Clan1 & 0.864 & & & \\
\hline Clan2 & 0.909 & 0.953 & 0.962 & 0.809 \\
\hline Clan3 & 0.906 & & & \\
\hline Clan4 & 0.915 & & & \\
\hline Clan5 & 0.895 & & & \\
\hline Clan6 & 0.908 & & & \\
\hline Developmental1 & 0.892 & & & 0.817 \\
\hline Developmental2 & 0.895 & 0.888 & 0.931 & \\
\hline Developmental3 & 0.924 & & & 0.737 \\
\hline ExternalOrien1 & 0.850 & & & \\
\hline ExternalOrien2 & 0.859 & 0.949 & 0.957 & \\
\hline ExternalOrien3 & 0.860 & & & \\
\hline ExternalOrien4 & 0.841 & & & \\
\hline ExternalOrien5 & 0.877 & & & \\
\hline ExternalOrien6 & 0.880 & & & \\
\hline ExternalOrien7 & 0.856 & & & \\
\hline ExternalOrien8 & 0.846 & & & \\
\hline Flexibility1 & 0.770 & 0.963 & 0.967 & \\
\hline Flexibility10 & 0.816 & & & \\
\hline Flexibility11 & 0.826 & & & \\
\hline
\end{tabular}




\section{Macrothink}

Business and Economic Research ISSN 2162-4860

\begin{tabular}{|c|c|c|c|c|}
\hline Flexibility 12 & 0.857 & & & \\
\hline Flexibility13 & 0.838 & & & \\
\hline Flexibility2 & 0.766 & & & \\
\hline Flexibility3 & 0.825 & & & \\
\hline Flexibility4 & 0.867 & & & \\
\hline Flexibility 5 & 0.879 & & & \\
\hline Flexibility6 & 0.856 & & & \\
\hline Flexibility7 & 0.844 & & & \\
\hline Flexibility8 & 0.850 & & & \\
\hline Flexibility9 & 0.839 & & & \\
\hline Hierarchical1 & 0.824 & 0.934 & 0.948 & 0.751 \\
\hline Hierarchical2 & 0.866 & & & \\
\hline Hierarchical3 & 0.901 & & & \\
\hline Hierarchical4 & 0.876 & & & \\
\hline Hierarchical5 & 0.880 & & & \\
\hline Hierarchical6 & 0.850 & & & \\
\hline NewOrganiz1 & 0.838 & 0.939 & 0.950 & 0.732 \\
\hline NewOrganiz2 & 0.858 & & & \\
\hline NewOrganiz3 & 0.889 & & & \\
\hline NewOrganiz4 & 0.827 & & & \\
\hline NewOrganiz5 & 0.835 & & & \\
\hline NewOrganiz6 & 0.869 & & & \\
\hline NewOrganiz7 & 0.870 & & & \\
\hline NewProduct1 & 0.779 & 0.935 & 0.947 & 0.720 \\
\hline NewProduct2 & 0.848 & & & \\
\hline NewProduct3 & 0.853 & & & \\
\hline NewProduct4 & 0.854 & & & \\
\hline NewProduct5 & 0.879 & & & \\
\hline NewProduct6 & 0.886 & & & \\
\hline NewProduct7 & 0.835 & & & \\
\hline OpenC1 & 0.876 & 0.960 & 0.966 & 0.781 \\
\hline OpenC2 & 0.918 & & & \\
\hline OpenC3 & 0.884 & & & \\
\hline OpenC4 & 0.908 & & & \\
\hline OpenCom1 & 0.846 & 0.919 & 0.943 & 0.804 \\
\hline OpenCom2 & 0.906 & & & \\
\hline OpenCom3 & 0.863 & & & \\
\hline OpenCom4 & 0.914 & & & \\
\hline OpenCom5 & 0.916 & & & \\
\hline OpenCom6 & 0.886 & & & \\
\hline OpenCom7 & 0.880 & & & \\
\hline OpenCom8 & 0.855 & & & \\
\hline Proactivity1 & 0.913 & 0.887 & 0.930 & 0.815 \\
\hline Proactivity2 & 0.914 & & & \\
\hline Proactivity3 & 0.879 & & & \\
\hline Rational1 & 0.885 & 0.888 & 0.931 & 0.817 \\
\hline Rational2 & 0.923 & & & \\
\hline Rational3 & 0.904 & & & \\
\hline Risk1 & 0.916 & 0.892 & 0.933 & 0.823 \\
\hline Risk2 & 0.930 & & & \\
\hline Risk3 & 0.875 & & & \\
\hline TeamWork1 & 0.877 & 0.961 & 0.966 & 0.762 \\
\hline TeamWork2 & 0.891 & & & \\
\hline TeamWork3 & 0.883 & & & \\
\hline
\end{tabular}




\begin{tabular}{|l|l|l|l|l|}
\hline TeamWork4 & 0.853 & & & \\
\hline TeamWork5 & 0.897 & & & \\
\hline TeamWork6 & 0.895 & & & \\
\hline TeamWork7 & 0.855 & & & \\
\hline TeamWork8 & 0.837 & & & \\
\hline TeamWork9 & 0.868 & & & \\
\hline
\end{tabular}

In this model the value range of Cronbach alpha is from 0.961 to 0.926 as shown in the above table that predicts the data is reliable to perform further tests. The connection of each variable to the primary factor is articulated is predicted by the factor loading.Therefore it shows that scales used for variables has convergent validity.

\subsubsection{Discriminant Validity}

This technique is implied to examine the difference between variables of the research framework.

Table 5. Fornell and Larcker Criteria

\begin{tabular}{|l|l|l|l|l|l|l|l|l|l|l|l|l|l|}
\hline & 1 & 2 & 3 & 4 & 5 & 6 & 7 & 8 & 9 & 10 & 11 & 12 & 13 \\
\hline Clan Culture 1 & 0.9 & & & & & & & & & & & & \\
\hline Developmental Culture 2 & 0.551 & 0.904 & & & & & & & & & & & \\
\hline External Orientation 3 & 0.38 & 0.381 & 0.859 & & & & & & & & & & \\
\hline Flexibility 4 & 0.547 & 0.38 & 0.629 & 0.834 & & & & & & & & & \\
\hline Hierarchical Culture 5 & 0.215 & 0.219 & 0.465 & 0.561 & 0.867 & & & & & & & & \\
\hline New Organizational Practice 6 & 0.547 & 0.541 & 0.252 & 0.372 & 0.279 & 0.855 & & & & & & & \\
\hline New Product Innovation 7 & 0.321 & 0.393 & 0.628 & 0.55 & 0.516 & 0.245 & 0.849 & & & & & & \\
\hline Open Communication 8 & 0.51 & 0.604 & 0.209 & 0.219 & 0.358 & 0.609 & 0.301 & 0.884 & & & & & \\
\hline Open Culture 9 & 0.568 & 0.557 & 0.281 & 0.25 & 0.367 & 0.522 & 0.408 & 0.706 & 0.897 & & & & \\
\hline Proactivity 10 & 0.303 & 0.402 & 0.588 & 0.421 & 0.443 & 0.231 & 0.557 & 0.373 & 0.39 & 0.903 & & & \\
\hline Rational Culture 11 & 0.342 & 0.357 & 0.511 & 0.476 & 0.457 & 0.23 & 0.547 & 0.358 & 0.291 & 0.497 & 0.904 & & \\
\hline Risk-Taking 12 & 0.443 & 0.546 & 0.377 & 0.383 & 0.289 & 0.604 & 0.265 & 0.496 & 0.404 & 0.354 & 0.321 & 0.907 & \\
\hline Team Work 13 & 0.528 & 0.531 & 0.193 & 0.353 & 0.371 & 0.588 & 0.297 & 0.728 & 0.656 & 0.3 & 0.319 & 0.498 & 0.873 \\
\hline
\end{tabular}

Fornell and Larcker Table, determines the extent of disparities between the overlying construct. Fornell and Larcker Table reveals the outcome of Discriminant validity as it exposes that how much any single factor is not the same as alternate factors in the model. Fornell and Larcker (1981) developed the test in which the mix affiliation between variables attained were compared and the transform eliminated estimations for the constructs building up every pair equivalent. According to Jaw (1998), the Discriminant validity is supported among variables which have an AVE more prominent than 0.5 entailing that no less than partial of inference variation was trapped by the variables. 
Table 6. Heterotrait-Monotrait Ratio (HTMT)

\begin{tabular}{|l|l|l|l|l|l|l|l|l|l|l|l|l|}
\hline & 1 & 2 & 3 & 4 & 5 & 6 & 7 & 8 & 9 & 10 & 11 & 12 \\
\hline Clan Culture & & & & & & & & & & & & \\
\hline Developmental Culture & 0.595 & & & & & & & & & & & \\
\hline External Orientation & 0.398 & 0.412 & & & & & & & & & & \\
\hline Flexibility & 0.569 & 0.408 & 0.656 & & & & & & & & & \\
\hline Hierarchical Culture & 0.225 & 0.239 & 0.492 & 0.589 & & & & & & & & \\
\hline New Organizational Practice & 0.577 & 0.587 & 0.266 & 0.389 & 0.297 & & & & & & & \\
\hline New Product Innovation & 0.339 & 0.428 & 0.666 & 0.577 & 0.552 & 0.258 & & & & & & \\
\hline Open Communication & 0.533 & 0.652 & 0.217 & 0.224 & 0.377 & 0.639 & 0.316 & & & & & \\
\hline Open Culture & 0.607 & 0.612 & 0.298 & 0.263 & 0.394 & 0.558 & 0.438 & 0.749 & & & & \\
\hline Proactivity & 0.326 & 0.448 & 0.637 & 0.448 & 0.481 & 0.251 & 0.607 & 0.401 & 0.430 & & & \\
\hline Rational Culture & 0.369 & 0.397 & 0.555 & 0.510 & 0.500 & 0.250 & 0.597 & 0.387 & 0.320 & 0.556 & & \\
\hline Risk-Taking & 0.479 & 0.610 & 0.406 & 0.409 & 0.315 & 0.658 & 0.289 & 0.534 & 0.444 & 0.395 & 0.358 & \\
\hline Team Work & 0.551 & 0.572 & 0.198 & 0.363 & 0.389 & 0.616 & 0.310 & 0.756 & 0.696 & 0.318 & 0.340 & 0.534 \\
\hline
\end{tabular}

Another method for checking the Discriminant validity is by using Heterotrait-Monotrait (HTMT) ratio of correlation. Henseler et al. (2015) anticipated the better functioning of this technique by Monte Carlo simulation study and established that HTMT is able to achieve higher specificity and sensitivity. HTMT values near to 1 show a lack of Discriminant validity. If the value of the HTMT is higher, this can be concluded that the data lack Discriminant validity.

HTMT values confirm the Discriminant validity of the model because all of the values of the variables are $<0.9$ and according to Henseler et al. (2015) it should be $<0.9$.

\subsubsection{Blind Folding}

A structural model analyzes the statistics concerning some endogenous latent variables to other latent variables. The most convenient feature in Partial Least Squares (PLS) method is that it can examine structural model and hypothesis through calculating path coefficients (Cohen, 1988). The hypotheses were tested by running a bootstrapping procedure as suggested by F.Hair Jr et al., (2014).

Table 7. Blind Folding

\begin{tabular}{|l|l|l|}
\hline & R2 & Q2 \\
\hline New Organizational Practice & 0.497 & 0.32 \\
\hline New Product Innovation & 0.547 & 0.65 \\
\hline Proactivity & 0.460 & 0.44 \\
\hline Risk-Taking & 0.408 & 0.43 \\
\hline
\end{tabular}

To analyze the connection between variables the values of R2 and Q2 are examined. The value less than 0.25 shows weak connection, value less than 0.50 shows moderate connection (Hair, Ringle \& Sarstedt, 2011) CMS has a strong connection shows by the value of R2 (Hair 2011), Q2 should be greater than zero which shows the overall model is fit (Stone \& Geisser, 
1974). Q2 value of the variable define that variables are the higher predictor for the model. The result of Q2 in above table is 0.595 which is greater than zero that demonstrates that the overall model is fit and recommended further.

\subsection{Structural Model Analysis}

Chin's (1998) recommended that for the procedure of bootstrapping 1,000 subsamples were executed to determine the statistical significance of all proposed paths coefficients.

\subsubsection{Hypothesis Testing}

In PLS-SEM, bootstrapping is one of the key steps, which gives the information of consistency of factor rough approximation. Sub-tests are drawn wherever from the primary model including replacement, in this procedure (Hair, Matthews, Matthews, and Sarstedt, 2017). Bootstrapping gives data on the solidness of the coefficient gauge. In this procedure, an enormous number of sub-tests are drawn from the first example with a substitution (Hair et al. 2016). In the wake of running the bootstrap schedule, SmartPLS shows the t-values for basic model appraisals got from the bootstrapping methodology. The aftereffects of way coefficients for all the speculations appear in the accompanying table. The t-esteem more prominent than $1.96(\mathrm{p}<.005)$ shows that the relationship is noteworthy at $95 \%$ certainty level $(\alpha=0.05)$. Ways indicating whether the connection among estimated and idle factors are noteworthy or not.

The value of the mention table represented the supported and not supported hypothesis of the research paper.

Table 8. Path Coefficients and Bootstrap Values Hypothesis Summary

\begin{tabular}{|c|c|c|c|c|c|}
\hline Hypothesis & Relationship & Original Sample & T-Statistic & P-Value & Support \\
\hline $\mathbf{H}_{1 \mathrm{a}}$ & Clan Culture -> New Organizational Practice & 0.173 & 1.661 & 0.097 & Supported \\
\hline $\mathbf{H}_{1 \mathrm{~b}}$ & Clan Culture -> New Product Innovation & -0.156 & 1.712 & 0.087 & Supported \\
\hline $\mathbf{H}_{1 \mathrm{c}}$ & Clan Culture -> Proactivity & -0.102 & 1.102 & 0.271 & Not-supported \\
\hline $\mathbf{H}_{1 \mathrm{~d}}$ & Clan Culture -> Risk-Taking & 0.061 & 0.558 & 0.577 & Not-supported \\
\hline $\mathbf{H}_{2 \mathrm{a}}$ & Hierarchical Culture -> New Organizational Practice & 0.008 & 0.098 & 0.922 & Not-supported \\
\hline $\mathbf{H}_{2 \mathrm{~b}}$ & Hierarchical Culture -> New Product Innovation_ & 0.112 & 1.493 & 0.136 & Not-supported \\
\hline $\mathbf{H}_{2 \mathrm{c}}$ & Hierarchical Culture -> Proactivity & 0.098 & 1.141 & 0.254 & Not-supported \\
\hline $\mathbf{H}_{2 \mathrm{~d}}$ & Hierarchical Culture -> Risk-Taking & 0.012 & 0.135 & 0.893 & Not-supported \\
\hline $\mathbf{H}_{3 \mathrm{a}}$ & Developmental Culture -> New Organizational Practice & 0.153 & 1.605 & 0.109 & Not-supported \\
\hline $\mathbf{H}_{3 \mathrm{~b}}$ & Developmental Culture -> New Product Innovation & 0.091 & 1.013 & 0.311 & Not-supported \\
\hline $\mathbf{H}_{3 \mathrm{c}}$ & Developmental Culture -> Proactivity & 0.095 & 1.189 & 0.235 & Not-supported \\
\hline $\mathbf{H}_{3 \mathbf{d}}$ & Developmental Culture -> Risk-Taking & 0.270 & 2.970 & 0.003 & Supported \\
\hline $\mathbf{H}_{4 \mathrm{a}}$ & Rational Culture -> New Organizational Practice & -0.122 & 1.250 & 0.212 & Not-supported \\
\hline $\mathbf{H}_{4 \mathrm{~b}}$ & Rational Culture -> New Product Innovation & 0.222 & 2.597 & 0.010 & Supported \\
\hline $\mathbf{H}_{4 \mathrm{c}}$ & Rational Culture -> Proactivity & 0.181 & 2.134 & 0.033 & Supported \\
\hline $\mathbf{H}_{4 d}$ & Rational Culture -> Risk-Taking & -0.014 & 0.169 & 0.866 & Not-supported \\
\hline $\mathbf{H}_{5 \mathrm{a}}$ & Open Culture -> New Organizational Practice & 0.005 & 0.045 & 0.964 & Not-supported \\
\hline $\mathbf{H}_{5 \mathrm{~b}}$ & Open Culture -> New Product Innovation & 0.282 & 2.610 & 0.009 & Supported \\
\hline $\mathbf{H}_{5 \mathrm{c}}$ & Open Culture -> Proactivity & 0.144 & 1.437 & 0.151 & Not-supported \\
\hline $\mathbf{H}_{5 d}$ & Open Culture -> Risk-Taking & -0.105 & 0.978 & 0.328 & Not-supported \\
\hline $\mathbf{H}_{6 \mathrm{a}}$ & Flexibility -> New Organizational Practice & 0.146 & 1.428 & 0.154 & Not-supported \\
\hline $\mathbf{H}_{6 \mathrm{~b}}$ & Flexibility -> New Product Innovation & 0.202 & 2.263 & 0.024 & Supported \\
\hline $\mathbf{H}_{6 c}$ & Flexibility -> Proactivity & 0.010 & 0.102 & 0.919 & Not-supported \\
\hline
\end{tabular}




\begin{tabular}{|l|l|l|l|l|l|}
\hline $\mathbf{H}_{\mathbf{6 d}}$ & Flexibility -> Risk-Taking & 0.052 & 0.489 & 0.625 & Not-supported \\
\hline $\mathbf{H}_{7 \mathbf{a}}$ & Open Communication -> New Organizational Practice & 0.309 & 2.570 & 0.010 & Supported \\
\hline $\mathbf{H}_{\mathbf{7 b}}$ & Open Communication -> New Product Innovation & -0.065 & 0.492 & 0.623 & Not-supported \\
\hline $\mathbf{H}_{\mathbf{7 c}}$ & Open Communication -> Proactivity & 0.119 & 1.079 & 0.281 & Not-supported \\
\hline $\mathbf{H}_{7 \mathbf{d}}$ & Open Communication -> Risk-Taking & 0.174 & 1.495 & 0.136 & Not-supported \\
\hline $\mathbf{H}_{\mathbf{8}}$ & External Orientation -> New Organizational Practice & -0.005 & 0.046 & 0.963 & Not-supported \\
\hline $\mathbf{H}_{\mathbf{8 b}}$ & External Orientation -> New Product Innovation & 0.304 & 3.360 & 0.001 & Supported \\
\hline $\mathbf{H}_{\mathbf{8 c}}$ & External Orientation -> Proactivity & 0.391 & 4.765 & 0.000 & Supported \\
\hline $\mathbf{H}_{\mathbf{8 d}}$ & External Orientation -> Risk-Taking & 0.171 & 1.843 & 0.066 & Supported \\
\hline $\mathbf{H}_{\mathbf{9}}$ & Team Work -> New Organizational Practice & 0.173 & 1.348 & 0.178 & Not-supported \\
\hline $\mathbf{H}_{\mathbf{9}}$ & Team Work -> New Product Innovation_- & -0.050 & 0.403 & 0.687 & Not-supported \\
\hline $\mathbf{H}_{\mathbf{9}}$ & Team Work -> Proactivity & -0.051 & 0.442 & 0.658 & Not-supported \\
\hline $\mathbf{H}_{\mathbf{9 d}}$ & Team Work -> Risk-Taking & 0.213 & 1.767 & 0.078 & Supported \\
\hline
\end{tabular}

The hypotheses between the independent variables and dependent variables were evaluated on the foundation of significance ( $\mathrm{p}<0.1$ ), sign and size (Wixom \& Watson, 2001). The results showed that new product innovation was positively influenced by Rational Culture, Open Culture, Flexibility, and External Orientation. And negatively affected by Clan Culture. Similarly, risk taking ability is positively influenced by Developmental Culture, External Orientation, and Team Work. Proactivity is positively affected by Rational Culture, and External Orientation. Unlike Innovation, which was negatively affected by Clan culture, New Organizational Practice got positively affected along with Open Communication. An approach calculates the indirect effect by multiplying two regression coefficients (Sobel, 1982).

The results showed that new product innovation was positively influenced by Rational Culture, Open Culture, Flexibility, and External Orientation. And negatively affected by Clan Culture. Similarly, risk taking ability is positively influenced by Developmental Culture, External Orientation, and Team Work. Proactivity is positively affected by Rational Culture, and External Orientation. Unlike Innovation, which was negatively affected by Clan culture, New Organizational Practice got positively affected along with Open Communication.

\section{Conclusion}

The objective of this research was to identify the impact of organizational culture on new product innovation, organizational practice, proactivity and risk taking. To achieve the objective of study instrument for organizational culture are; clan culture, hieratical culture, developmental culture, rational culture, open culture, flexibility/ support to change, open communication, external orientation and teamwork are derived from different studies done before in different time frame and different countries.

The sample chosen for this research paper is 300 out of 320. In this research project, primary data had been collected by using survey questionnaires method. The discriminant validity and reliability of data was confirmed to validate the authenticity of the instrument. The data was screened through different method. The reliability, validity and SEM analysis were tested through Smart PLS 3. The reliability and validity of indicator was check through Log Algorithm path and for SEM analysis bootstrapping sample were used and for predictive 
relevance the option of blindfolding is used.

The present study contributes to the literature on Organizational culture to the new innovation process, organizational practice, pro-activity and risk-taking in different way. First, our results show that clan culture of any organization will definitely effect the new organizational practice and new product innovation of an organization because clan culture elaborates the unity, togetherness and whenever an organization have a clan culture it will deliver good results.

But on the other hand the strange result was seen that the hierarchical culture do not support any of our dependent variables. It may be due to the dominancy of the upper management on the employees. And also there is lack of communication between the departments or rivalry among the departments which undeniably effect the organization culture and fail to contribute in positive results. Also Developmental culture and team work only support the risk-taking by organization. It may be because whenever an organization decide to take risk for any project or any idea or any innovation, it require a culture within the organization which has the capability to work for the development and work within a team to achieve positive results. Also organizational factors like external orientation, flexibility, open communication, open culture and rational culture has significant effect on the new product innovation. Because whenever an organization provide free culture to the employees it absolutely provide positive results in future and in innovation of product.

A lot of researches were conducted on organizational culture and entrepreneurial orientation but no one has ever conduct a comparative or nexus research in which organizational culture was measured by teamwork, external orientation, developmental culture, rational culture, clan culture, open culture, open communication, flexibility/ support to change, hierarchical culture (altogether) and entrepreneurial orientation was measured by innovativeness, risk-taking, new organizational practice and proactiveness (altogether). This study has been positively contribute in this era because the working employees has giving their opinion through questionnaire and the conclusion support the organizations for better innovation of product, for new organizational practice, for proactive behavior and for taking risk.

\subsection{Limitations}

The research is purely based on employees who are currently working in any organization so to distribute and collect questionnaire in due time was a tough duty, and this gives a negative impact on the data gathering and on the subject of research. Due to the limitation of time this study will have some lacking in context. Also facing trouble to get to the organization's inside data.

Moreover, the research work is conducted for the employees who are currently working in any organization because the data is easily accessible. In this research we did not analyze any specific sector. In order to get accurate result, we randomly select employees. . The findings of study are based on the test results which have been applied on the questionnaires filled online and manually as well. The research has not been applied on any organization and has been done for academic purpose. 


\section{References}

Abdullah, N. H., Shamsuddin, A., Wahab, E., \& Hamid, N. A. A. (2014). The relationship between organizational culture and product innovativeness. Procedia-Social and Behavioral Sciences, 129, 140-147. https://doi.org/10.1016/j.sbspro.2014.03.659

Arz, C. (2017). Mechanisms of organizational culture for fostering corporate entrepreneurship: A systematic review and research agenda. Journal of enterprising culture, 25(04), 361-409. https://doi.org/10.1142/S0218495817500145

Atiyabi, F., Livari, M. A., \& Kaviani, K. (2007). Statistical analysis of heart beat time series. Iranian Journal of Physics Research, 7(1), 53-59.

Awadh, A. M., \& Alyahya, M. S. (2013). Impact of organizational culture on employee performance. International review of management and business research, 2(1), 168.

http://dx.doi.org/10.5539/ijbm.v8n2p63

Brettel, M., Chomik, C., \& Flatten, T. C. (2015). How organizational culture influences innovativeness, proactiveness, and risk-taking: Fostering entrepreneurial orientation in SMEs. Journal of Small Business Management, 53(4), 868-885. https://doi.org/10.1111/jsbm.12108

Bunderson, J. S., \& Sutcliffe, K. M. (2003). Management team learning orientation and business unit performance. Journal of Applied Psychology, 88(3), 552.

https://doi.org/10.1037/0021-9010.88.3.552

Carlsson, S., Corvello, V., Inauen, M., \& Schenker-Wicki, A. (2011). The impact of outsidein open innovation on innovation performance. European Journal of Innovation Management. https://doi.org/10.1108/14601061111174934

Cherchem, N. (2017). The relationship between organizational culture and entrepreneurial orientation in family firms: Does generational involvement matter? Journal of family business strategy, 8(2), 87-98. https://doi.org/10.1016/j.jfbs.2017.04.001

Chirico, F., \& Nordqvist, M. (2010). Dynamic capabilities and trans-generational value creation in family firms: The role of organizational culture. International Small Business Journal, 28(5), 487-504. https://doi.org/10.1177/0266242610370402

Cohen, N. J., McCloskey, M., \& Wible, C. G. (1988). There is still no case for a flashbulb-memory mechanism: Reply to Schmidt and Bohannon.

https://doi.org/10.1037/0096-3445.117.3.336

Cornwall, J. R., \& Perlman, B. (1990). Organizational entrepreneurship. McGraw-Hill/Irwin.

Covin, J. G., \& Slevin, D. P. (1991). A conceptual model of entrepreneurship as firm behavior. Entrepreneurship theory and practice, 16(1), 7-26.

https://doi.org/10.1177/104225879101600102

Cronbach, L. J. (1951). Coefficient alpha and the internal structure of tests. psychometrika, 16(3), 297-334. https://doi.org/10.1007/BF02310555 


\section{$\triangle$ Macrothink}

Business and Economic Research ISSN 2162-4860 2020, Vol. 10, No. 3

Dijkstra, T. K., \& Henseler, J. (2015). Consistent partial least squares path modeling. MIS quarterly, 39(2). https://doi.org/10.25300/MISQ/2015/39.2.02

Ekvall, G. (1996). Organizational climate for creativity and innovation. European Journal of Work and Organizational Psychology, 5(1), 105-123.

https://doi.org/10.1080/13594329608414845

Engelen, A., Flatten, T. C., Thalmann, J., \& Brettel, M. (2014). The effect of organizational culture on entrepreneurial orientation: A comparison between Germany and Thailand. Journal of small business management, 52(4), 732-752. https://doi.org/10.1111/jsbm.12052

Faiz, E., \& Uludag, G. (2019). Entrepreneurial Orientation of Family Business: A Case Study From Turkey. In Handbook of Research on Entrepreneurship, Innovation, and Internationalization (pp. 133-156). IGI Global.

https://doi.org/10.4018/978-1-5225-8479-7.ch005

Fornell, C., \& Larcker, D. F. (1981). Structural equation models with unobservable variables and measurement error: Algebra and statistics. https://doi.org/10.1177/002224378101800313

George, B. C., Bohnen, J. D., Williams, R. G., Meyerson, S. L., Schuller, M. C., Clark, M. J., \& Smink, D. S. (2017). Readiness of US general surgery residents for independent practice. Annals of surgery, 266(4), 582-594. https://doi.org/10.1097/SLA.0000000000002414

Gursoy, A., \& Guven, B. (2016). Effect of innovative culture on intrapreneurship. International Journal of Business and Social Science, 7(1), 152-162.

Hair Jr, J. F., Matthews, L. M., Matthews, R. L., \& Sarstedt, M. (2017). PLS-SEM or CB-SEM: updated guidelines on which method to use. International Journal of Multivariate Data Analysis, 1(2), 107-123. https://doi.org/10.1504/IJMDA.2017.087624

Harkema, S. (2003). A complex adaptive perspective on learning within innovation projects. The learning organization. https://doi.org/10.1108/09696470310497177

Hayes, A. F., \& Scharkow, M. (2013). The relative trustworthiness of inferential tests of the indirect effect in statistical mediation analysis: Does method really matter?. Psychological science, 24(10), 1918-1927. https://doi.org/10.1177/0956797613480187

Henseler, J., Hubona, G., \& Ray, P. A. (2016). Using PLS path modeling in new technology research: updated guidelines. Industrial Management \& Data Systems.

https://doi.org/10.1108/IMDS-09-2015-0382

Hoque, N., Khan, M. A., \& Mowla, M. (2013). Organisational culture: features and framework from Islamic perspective. Humanomics. https://doi.org/10.1108/H-06-2013-0040

Iivari, J., \& Huisman, M. (2007). The relationship between organizational culture and the deployment of systems development methodologies. Mis Quarterly, 35-58.

https://doi.org/10.2307/25148780

Katila, R., \& Ahuja, G. (2002). Something old, something new: A longitudinal study of search behavior and new product introduction. Academy of Management Journal, 45(6), 
1183-1194. https://doi.org/10.5465/3069433

Laforet, S. (2016). Effects of organisational culture on organisational innovation performance in family firms. Journal of Small Business and Enterprise Development, 23(2), 379-407. https://doi.org/10.1108/JSBED-02-2015-0020

Laursen, K., \& Salter, A. (2006). Open for innovation: the role of openness in explaining innovation performance among UK manufacturing firms. Strategic Management Journal, 27(2), 131-150. https://doi.org/10.1002/smj.507

Li, K., Griffi, N. D., Yue, H., \& Zhao, L. (2013). How does culture influence corporate risk-taking? Journal of Corporate Finance, 23, 1-22

https://doi.org/10.1016/j.jcorpfin.2013.07.008

Lu, A. C. C., \& Gursoy, D. (2016). Impact of job burnout on satisfaction and turnover intention: do generational differences matter?. Journal of Hospitality \& Tourism Research, 40(2), 210-235. https://doi.org/10.1177/1096348013495696

Martín-de Castro, G., López-Sáez, P., Delgado-Verde, M., Donate, M. J., \& Guadamillas, F. (2011). Organizational factors to support knowledge management and innovation. Journal of knowledge management. https://doi.org/10.1108/13673271111179271

Miller, D., \& Friesen, P. H. (1983). Strategy-making and environment: the third link. Strategic management journal, 4(3), 221-235. https://doi.org/10.1002/smj.4250040304

Nordqvist, M., \& Melin, L. (2010). Entrepreneurial families and family firms. Entrepreneurship \& Regional Development, 22(3-4), 211-239.

https://doi.org/10.1080/08985621003726119

Pauwels, K., Silva-Risso, J., Srinivasan, S., \& Hanssens, D. M. (2004). New products, sales promotions, and firm value: The case of the automobile industry. Journal of marketing, 68(4), 142-156. https://doi.org/10.1509/jmkg.68.4.142.42724

Prajogo, D. I., \& McDermott, C. (2011). The relationship between multidimensional organizational culture and performance. International Journal Operations \& Production Management, 31(7), 712-735. https://doi.org/10.1108/01443571111144823

Pullen, A., de Weerd-Nederhof, P., Groen, A., Song, M., \& Fisscher, O. (2009). Successful patterns of internal SME characteristics leading to high overall innovation performance. Creativity and Innovation Management, 18(3), 209-223.

https://doi.org/10.1111/j.1467-8691.2009.00530.x

Radas, S., \& Bozic, L. (2009). The antecedents of SME innovativeness in an emerging transition economy. Technovation, 29(6/7), 438-450.

https://doi.org/10.1016/j.technovation.2008.12.002

Rass, M., Dumbach, M., Danzinger, F., Bullinger, A. C., \& Moeslein, K. M. (2013). Open innovation and firm performance: the mediating role of social capital. Creativity and innovation management, 22(2), 177-194. https://doi.org/10.1111/caim.12028 
Reinartz, W., Krafft, M., \& Hoyer, W. D. (2004). The customer relationship management process: measurement and impact on performance. Journal of Marketing Research, 41(3), 293-305. https://doi.org/10.1509/jmkr.41.3.293.35991

Riivari, E., Lämsä, A. M., Kujala, J., \& Heiskanen, E. (2012). The ethical culture of organisations and organisational innovativeness. European Journal of Innovation Management. https://doi.org/10.1108/14601061211243657

Ringle, C. M., Wende, S., \& Will, A. (2005). SmartPLS 2.0 M3 Beta.

Ringle, W. S., \& Becker, J. (2015). SmartPLS 3. Boenningstedt: SmartPLS GmbH.

Rószkiewicz, M., \& Strzyżewska, M. (2011). The relationship between the commitment to internationalization and economic cooperation and changes in the level of sales profitability of Polish enterprises. The results of the empirical study, Management and Finance, 4(8), 319-331.

Salavou, H., \& Avlonitis, G. (2008). Product innovativeness and performance: a focus on SMEs. Management Decision, 46(7), 969-985. https://doi.org/10.1108/00251740810890168

Salavou, H., Baltas, G., \& Lioukas, S. (2004). Organisational innovation in SMEs: the importance of strategic orientation and competitive structure. European Journal of Marketing, 38(9), 1091-1112. https://doi.org/10.1108/03090560410548889

Sarstedt, M., Ringle, C. M., Henseler, J., \& Hair, J. F. (2014). On the emancipation of PLS-SEM: A commentary on Rigdon (2012). Long range planning, 47(3), 154-160. https://doi.org/10.1016/j.lrp.2014.02.007

Shahzad, F., Xiu, G., \& Shahbaz, M. (2017). Organizational culture and innovation performance in Pakistan's software industry. Technology in Society, 51, 66-73.

https://doi.org/10.1016/j.techsoc.2017.08.002

Shrout, P. E., \& Bolger, N. (2002). Mediation in experimental and nonexperimental studies: new procedures and recommendations. Psychological Methods, 7(4), 422.

https://doi.org/10.1037/1082-989X.7.4.422

Singh, T., \& Modassir, A. (2007). Relationship of emotional intelligence with transformational leadership and organizational citizenship behavior. IIM Bangalore Research Paper, pp. 262. https://dx.doi.org/10.2139/ssrn.2145266

Sobel, M. E. (1982). Asymptotic confidence intervals for indirect effects in structural equation models. Sociological Methodology, 13, 290-312. https://doi.org/10.2307/270723

Stone, M. (1974). Cross-validatory choice and assessment of statistical predictions. Journal of the Royal Statistical Society: Series B (Methodological), 36(2), 111-133.

https://doi.org/10.1111/j.2517-6161.1974.tb00994.x

Tabachnick, B. G., Fidell, L. S., \& Ullman, J. B. (2007). Using multivariate statistics (Vol. 5). Boston, MA: Pearson. 


\section{Macrothink}

Business and Economic Research ISSN 2162-4860 2020, Vol. 10, No. 3

Tanewski, G. A., Prajogo, D., \& Sohal, A. (2003). Strategic orientation and innovation performance between family and non-family firms. Presented at the World Conference of the International Council of Small Business, Monash University, Belfast.

Thorne, J. H., Cameron, D., \& Quinn, J. F. (2006). A conservation design for the central coast of California and the evaluation of mountain lion as an umbrella species. Natural Areas Journal, 26(2), 137-148. https://doi.org/10.3375/0885-8608(2006)26[137:ACDFTC]2.0.CO;2

Wixom, B. H., \& Watson, H. J. (2001). An empirical investigation of the factors affecting data warehousing success. MIS quarterly, 17-41. https://doi.org/10.2307/3250957

Zahra, S. A. (2008). The virtuous cycle of discovery and creation of entrepreneurial opportunities. Strategic Entrepreneurship Journal, 2(3), 243-257.

https://doi.org/10.1002/sej.47

Zikmund, W. G., Babin, B. J., Carr, J. C., \& Griffin, M. (2003). Business research methods (ed.). Thomson/South-Western, Cincinnati, $\mathrm{OH}$.

\section{Copyright Disclaimer}

Copyright for this article is retained by the author(s), with first publication rights granted to the journal.

This is an open-access article distributed under the terms and conditions of the Creative Commons Attribution license (http://creativecommons.org/licenses/by/4.0/). 